\title{
A.D. 672 - The Apex of Apocalyptic Thought in the Early Medieval Latin West?
}

In Late Antiquity and the early Middle Ages, the Second Coming of Christ was connected to the beginning of the seventh millennium. This raised apocalyptic expectations for the end of sixth millennium. When exactly this was to take place depended on how one counted the years since Creation. Three different methods of counting were introduced successively, with Christ's birth in AM 5500 (AMI), AM 5200 (AMII), and 3952 (AMIII). AMII replaced AMI roughly 100 years before AMI would have reached the end of the sixth millennium, and the same applies to AMIII replacing AMII. The general assumption is that the introduction of a new count that pushed the end of the sixth millennium back by a few centuries is a significant indicator of widespread apocalyptic anxiety. This article analyses countdowns to the end of the sixth millennium according to AMII $(A M 6000=A . D$. 800). It concludes that these do not reflect bottom-up reactions to apocalyptic fear, but are rather the product of debates among the Christian intellectual elite about scientific-theological issues.

\section{Introduction}

The sixth-century text known as De excidio et conquestu Britanniae, ascribed to a certain Gildas by both Columbanus and Bede, describes in detail the conquest of late Roman, Christian Britain by the pagan Saxons, its prehistory, causes and consequences. ${ }^{1}$ Starting with the Roman invasion, Gildas recounts the Britons' conversion to Christianity, the withdrawal of the Roman legions that left the British areas exposed to Irish and Pictish raiding, the resulting British call for aid to the pagan Saxons, whose support turned to oppression. He ends with a scathing rebuke of secular Briton leadership becoming tyrannical and ecclesiastical values being undermined by mortal sins. The text's rhetoric and imagery are decidedly apocalyptic. According to Gildas, the Saxon enemy's devastation of the country and a subsequent famine that further decimated the population were not taken seriously as signs of divine displeasure. In the ensuing phase of growth, the Britons, "welcoming Satan as an angel of light” (exceptio Satanae pro angelo lucis), succumbed to vices and ungodli-

1 For the problems in dating Gildas's work, see especially O'Sullivan, De excidio of Gildas; an earlier date is proposed by Higham, The English Conquest, 118-145; for a recent summary of the debate, see Schustereder, Strategies of Identity Construction, 74-79.

Note: I gratefully acknowledge that part of this research was funded by the Irish Research Council as part of the Laureate Consolidator Award Scheme.

๖ Open Access. () 2020 Immo Warntjes, published by De Gruyter. (ख) BY-Nc-ND This work is licensed under the Creative Commons Attribution-NonCommercial-NoDerivatives 4.0 License.

https://doi.org/10.1515/9783110597745-028 
ness; God, therefore, "wished to purge his family" (volente deo purgare familiam suam) and caused the pagan enemy to return, this time accompanied by plague. The barbarian Saxons brought "just punishment of the crimes that had gone before" (ultionis iustae praecedentium scelerum); British slavery ensued, but in his mercy, the Lord granted the Britons another victory. However, they again reverted to their vices, kings turned into tyrants, simony prevailed, and clerics became false prophets and "instruments of the devil" (diabolica organa). ${ }^{2}$ Gildas concludes:

[...] except for yourselves, who are held bound so tight with iniquities in this world that you cannot at all ascend to heaven, but must fall into the dreadful dungeons of hell, if you do not turn to the Lord in this life? Nor should any priest applaud himself solely because he is conscious that his own body is pure: for if some of those he is in charge of die because of his ignorance or laziness or flattery, their souls shall be required on judgement day from his hands as though he had killed them. Death comes no sweeter from the hand of a good man than that of a bad. [...] May the almighty God of all consolation and pity preserve the very few good shepherds from all harm, and, conquering the common enemy, make them citizens of the heavenly city of Jerusalem, that is, of the congregation of all the saints, the Father, the Son, and the holy spirit, to whom be honour and glory for ever and ever, Amen. ${ }^{3}$

Gildas's letter is not explicitly linked to the last book of the Bible - it is not a commentary on the Book of Revelation - but it uses apocalyptic rhetoric and imagery. Indeed, while there are few early medieval commentaries on Revelation, ${ }^{4}$ Gildas's work is a prime example that early medieval authors nevertheless did write about the End Times, though perhaps not using the genres that modern scholars have labelled "apocalyptic writings". ${ }^{5}$ Gildas provides us with many features characteristic of authors who employ apocalyptic narratives in the early Middle Ages. The follow-

2 The quotes from Gildas, De excidio et conquestu Britanniae, 21-22, 24, 67, ed. Mommsen, 37, 39, 64; trans. Winterbottom, Gildas, 13-79, at 24, 25, 27, 54. For the question of literary topoi vs historical fact in Gildas's work, see McKee, “Gildas: Lessons from History;” for Gildas's rationale and rhetoric, see Higham, English Conquest, 7-89, 146-202.

3 Gildas, De excidio et conquestu Britanniae, 109-110, ed. Mommsen, 85: [...] praeter vosmetipsos, qui ita ligati iniquitatibus in hoc mundo tenemini, ut in caelis nequamquam ascendatis, sed infaustis tartari ergastulis, non conversi in hac vita ad dominum decidatis? Nec sibi quisquam sacerdotum de corporis mundi solum conscientia supplaudat, cum eorum quis praeest, si qui propter eius imperitiam vel desidiam seu adulationem perierint, in die iudicii de eiusdem manibus, veluti interfectoris, animae exquirantur. quia nec dulcior mors quae infertur a bono quoque homine quam malo. [...] Ipse omnipotens deus totius consolationis et misericordiae paucissimos bonos pastores conservet ab omni malo et municipes faciat subacto communi hoste civitatis Hierusalem caelestis, hoc est, sanctorum omnium congregationis, pater et filius et spiritus sanctus, cui sit honor et gloria in saecula saeculorum. Amen; transl. Winterbottom, Gildas, 79.

4 For overviews of early medieval apocalypse commentaries, see Matter, "The Apocalypse in Early Medieval Exegesis," and Matter, "Exegesis of the Apocalypse in the Early Middle Ages” (a reworking of the aforementioned article); Schipper, "Bede's Commentary on the Apocalypse and the Carolingians;" Poole, “The Western Apocalypse Commentary Tradition of the Early Middle Ages.” 5 This underlies the overview by Palmer, The Apocalypse in the Early Middle Ages. 
ing more general considerations, some of which are also applicable to Gildas's work, may help our understanding and interpretation of such texts:

- Writing was almost exclusively in the hands of a Christian, intellectual elite of considerable spiritual, political, and economic power, whose prime legitimisation was Christianity. Should the link between this elite and religion be questioned or undermined, its status and privileges were at risk.

- There were external and internal factors that could challenge or threaten the close link between this elite and Christianity. Potential external factors threatening the elite's dominance included, most prominently, military defeat at the hand of a pagan force (such as Irish and Pictish raiders, the Germanic invaders of Gildas's narrative; and in later centuries the Saracens, Vikings, and Hungarians), which demonstrated Christian military (if not spiritual) inferiority. The Christian elite's role was to safeguard God's blessing of society, and military defeat and other external factors, like famine, plague, extreme weather, and celestial phenomena, were interpreted as signs of God's displeasure with society's behaviour and thus indicators of the elite's failure to fulfill its prime task. The most obvious internal factor that could undermine the elite's status was internal power-struggles, its members' shortcomings in honouring their own set of moral values, or accusations of heresy.

- In such times of crisis, Christian intellectuals responded in two ways, depending on their status. Those in power, in the highest ecclesiastical and thus also political positions, tried to divert the blame that would naturally be directed at them by pointing the finger at their ecclesiastical opposition, secular rulers, or society more generally. In such cases, the Christian elite styled itself not so much as the guardians of society's well-being, but as the interpreters of God's will. This method was so effective that apocalyptic narratives were regularly employed to cement privilege and power. Those among the intellectual Christian elite who did not hold high office or enjoy power, privilege, and authority, but only aspired to these, used also external, but particularly internal shortcomings of the higher-ranked clergy in order to undermine the latter's authority and position themselves as potential successors of higher moral integrity.

If, then, writing the apocalypse was an ideal instrument used by the Christian elite to retain its privileges and to preserve the social hierarchy (or as a short-cut to gain access to higher status), is it still possible to trace more widespread apocalyptic anxiety? In other words, do early medieval texts employing apocalyptic narratives only reflect discourses that were triggered within the Christian elite and directed at its relation to secular power holders, or can we detect in them also "bottom-up" concerns? Were the writings of the intellectual elite informed by apocalyptic fears among the general population? 


\section{Early Medieval Countdowns}

The genre most indicative of widespread apocalyptic anxiety may be a substantial corpus of "countdowns" to the end of the sixth millennium. These are brief accounts positioning the author's annus praesens in the wider context of salvation history by counting the years from the creation of the world to the time of writing, and then indicating the number of years left until the second coming of Christ. This corpus was inspired by the second-century Letter of Barnabas, whose author combined the six days of creation with the psalmist's statement that one day of the Lord is like 1000 years into the theory that the second coming of Christ would occur at the end of the sixth millennium. ${ }^{6}$ When exactly the sixth millennium was going to end obviously depended on the calculation of how many years had passed since creation (AM = anni mundi). The early Middle Ages principally knew three different ways of reckoning the age of the world, labelled AMI, AMII, and AMIII after Richard Landes's classification in his seminal article of $1988 .^{7}$ AMI goes back to the writings of Hippolytus of Rome and Julianus Africanus in the third century, who both dated the birth of Christ to AM 5500; the end of the sixth millennium would therefore occur in A.D. 500. ${ }^{8}$ AMII is the Septuagint-based count of Eusebius of Caesarea, known in the Latin West through Jerome's translation of A.D. 381/382. According to Eusebius's calculation, Christ's birth took place in AM 5199/5200, and the sixth millennium would therefore end in A.D. 799/800. ${ }^{9}$ AMIII is the Vulgate count popularised by Bede in the eighth century, according to which Christ was born in AM 3952. Bede's method was not used for calculating the end of the world, as his more prominent use of anni domini (A.D.), still in use today, gave rise to the belief that the second coming of Christ would occur a millennium after the first coming, i.e. in A.D. 1000 (or any other year suggested by recalculations of A.D. chronology). ${ }^{10}$

Richard Landes drew attention to the phenomenon that AMI was widely replaced by AMII, and AMII in turn by AMIII, shortly before the end of the sixth

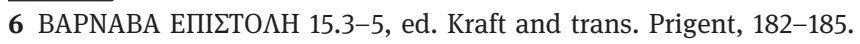

7 Landes, "Lest the Millenium Be Fulfilled."

8 See especially Mosshammer, The Easter Computus and the Origins of the Christian Era, 327-329, 387-421; also Rühl, Chronologie des Mittelalters und der Neuzeit, 190-191; Haeusler, Das Ende der Geschichte in der mittelalterlichen Weltchronistik, 7-23.

9 See Mosshammer, The Chronicle of Eusebius and the Greek Chronographic Tradition, 78; Burgess and Witakowski, Studies in Eusebian and Post-Eusebian Chronography, 79-84.

10 See, most prominently, Fried, Aufstieg aus dem Untergang; Fried, "Endzeiterwartung um die Jahrtausendwende;" Landes, "The Fear of an Apocalyptic Year 1000;" and the essays assembled in Apocalyptic Year 1000, ed. Landes, Gow, and Meter, which includes the two articles just mentioned, Fried's in English translation. For the re-calculations of the incarnation era, see now Verbist, Duelling with the Past; Nothaft, Dating the Passion, 103-112, and Nothaft, "An Eleventh-Century Chronologer at Work." 
millennium was reached according to their respective calculations. According to Landes, this was not coincidental - quite the contrary. He argued that this phenomenon proves how seriously the issue was taken in the early Middle Ages: the belief that the world would come to a close at the end of the sixth millennium was so widespread and created such a dynamic of apocalyptic fear that it forced the intellectual elites to revise their count, each time pushing the end of the sixth millennium back by a few hundred years, in order to calm the faithful and restore order.

In Landes's reading, calculations counting down to the end of the sixth millennium (here termed chronological millennialism) are the type of text most indicative of widespread apocalyptic fear. ${ }^{11}$ The biggest corpus of such countdowns survives for AMII, according to which the sixth millennium ended in A.D. 799/800. So far, I have been able to identify 15 witnesses (see Table 1); surely many more are yet to be found in the manuscripts. These countdowns appear in five different manuscript contexts (column 3 in Table 1): ${ }^{12}$ in contexts 1 and 2), they appear as continuations to Isidore's or Fredegar's chronicles, respectively; in context 3) as conclusions to short tracts counting the number of years from the creation of the world to the present year (summae annorum), all written from a Frankish perspective; in context 4) in connection with Easter calculations (computus), principally the one invented by Victorius of Aquitaine in A.D. 457; and in context 5) as part of an Iberian tradition that is unconnected to Isidore.

The beauty of these countdowns is that most of them can be securely placed in space and time (columns 1 and 4 in Table 1). This is because they typically do include not only a reference to the annus praesens of the author (from which the number of years to the end of the sixth millennium are counted down), but also to the reigning king, which gives them geographical anchorage.

Tab. 1: Countdowns relating to AMII

\begin{tabular}{llll}
\hline A.D. & transmission & context & geographic reference \\
\hline 644 & $\begin{array}{l}\text { poem Deus a quo facta fuit } \\
\text { (MGH Poetae 4.2, 695-7) }\end{array}$ & 4 - Victorian computus & $\begin{array}{l}\text { Domnall mac Áedo of Cenél } \\
\text { Conaill - northern Ireland / } \\
\text { western Scotland }\end{array}$ \\
\hline 649 & Würzburg UB Mp. th. f. 28 & $\begin{array}{l}\text { 3- Frankish summae } \\
\text { annorum }\end{array}$ & Sigebert III - Austrasia \\
(?) & (saec. VIII) & & \\
\hline
\end{tabular}

11 For a definition of this term and the countdowns discussed below, see Warntjes, "The Final Countdown and the Reform of the Liturgical Calendar in the Early Middle Ages," 51-55. Haeusler's approach (Das Ende der Geschichte in der mittelalterlichen Weltchronistik, especially 23-32) of just focusing on the most prominent world-chronicles, not their recensions, or smaller texts, neglects this corpus in its entirety.

12 See Warntjes, "The Final Countdown and the Reform of the Liturgical Calendar in the Early Middle Ages,” 56-61. 


\begin{tabular}{|c|c|c|c|}
\hline A.D. & transmission & context & geographic reference \\
\hline 658 & $\begin{array}{l}\text { Oxford, Bodleian Library, } \\
\text { Bodley } 309 \text { (saec. XI), 95v; } \\
\text { Tours BM } 334 \text { (A.D. 819), 17v; } \\
\text { Geneva BU } 50 \text { (A.D. 804?), } \\
\text { 133r; Paris BnF Lat. } 16361 \\
\text { (saec. XII), p. } 241 .\end{array}$ & 4 - Victorian computus & $\begin{array}{l}\text { Suibne mac Commáin of the } \\
\text { Déisi - mid-eastern Ireland }\end{array}$ \\
\hline [672] & León AC 8 (saec. XI), 25v & 5 - Iberian tradition & Wamba - Visigothic Spain \\
\hline 672 & $\begin{array}{l}\text { Paris BnF Lat. } 17544 \\
\text { (saec. XII), 114r; Vatican BAV } \\
\text { Reg. lat. 294; Venice BM Lat. } \\
\text { II 47; Vienna ÖNB } 4831\end{array}$ & $\begin{array}{l}1 \text { - Continuations of Isi- } \\
\text { dore's chronicles }\end{array}$ & $\begin{array}{l}\text { Chlothar III - Neustria and } \\
\text { Burgundy (Bourges / north- } \\
\text { east Aquitaine) }\end{array}$ \\
\hline 673 & $\begin{array}{l}\text { Milan BA H } 150 \text { inf. (saec. IX), } \\
\text { 129v }\end{array}$ & 4 - Victorian computus & $\begin{array}{l}\text { Chlothar III - Neustria and } \\
\text { Burgundy (the MS context } \\
\text { favours Burgundy) }\end{array}$ \\
\hline 675 & $\begin{array}{l}\text { Oxford BL e Mus. } 113 \text { (saec. X/ } \\
\text { XI), 114v-115r }\end{array}$ & $\begin{array}{l}\text { 3- Frankish summae anno- } \\
\text { rum }\end{array}$ & $\begin{array}{l}\text { Theuderic III - Neustria and } \\
\text { Burgundy (the textual con- } \\
\text { text suggests Neustria) }\end{array}$ \\
\hline [699] & $\begin{array}{l}\text { Bremen UB msc } 0046 \text { (c.A.D. } \\
\text { 900), 38v }\end{array}$ & 4 - Victorian computus & \\
\hline [715] & $\begin{array}{l}\text { Paris BnF Lat. } 10910 \\
\text { (A.D. 715?), 184r }\end{array}$ & $\begin{array}{l}2 \text { - cross-reference to Fre- } \\
\text { degar's text }\end{array}$ & \\
\hline 727 & $\begin{array}{l}\text { Dial. Burg. } 17 \text { (Borst, Schriften } \\
\text { zur Komputistik im Franken- } \\
\text { reich, 374: Bern BB } 611 \text { (saec. } \\
\mathrm{VIII}^{1 / 2} \text { ), 96v }\end{array}$ & 4 - Victorian computus & \\
\hline 736 & $\begin{array}{l}\text { First continuation of Fredegar } \\
\text { (MGH SS rer. Merov. } 2,176)\end{array}$ & 2 - continuation of Fredegar & \\
\hline $\begin{array}{l}738 \\
(+ \\
768)\end{array}$ & $\begin{array}{l}\text { London BL Cotton Nero A II } \\
\text { (saec. XI), 36r }\end{array}$ & $\begin{array}{l}\text { 3- Frankish summae anno- } \\
\text { rum }\end{array}$ & \\
\hline 742 & $\begin{array}{l}\text { Madrid BUC } 134 \text { (saec. XIII), } \\
\text { 25v }\end{array}$ & 5 - Iberian tradition & \\
\hline 747 & $\begin{array}{l}\text { Florence BML Plut. } 20.54 \\
\text { (saec. X), 15v }\end{array}$ & 4 - Victorian computus & $\begin{array}{l}\text { Lombard King Rachis - } \\
\text { northern Italy }\end{array}$ \\
\hline 786 & $\begin{array}{l}\text { Beatus of Liébana, In } \\
\text { apocalypsin IV } 5.16\end{array}$ & 5 - Iberian tradition & $\begin{array}{l}\text { Beatus of Liébana (author) } \\
\text { - northern Iberia (Asturias) }\end{array}$ \\
\hline
\end{tabular}

If these countdowns were indicative of widespread apocalyptic fear, they would allow us to map this phenomenon in seventh- and eighth-century Europe: 


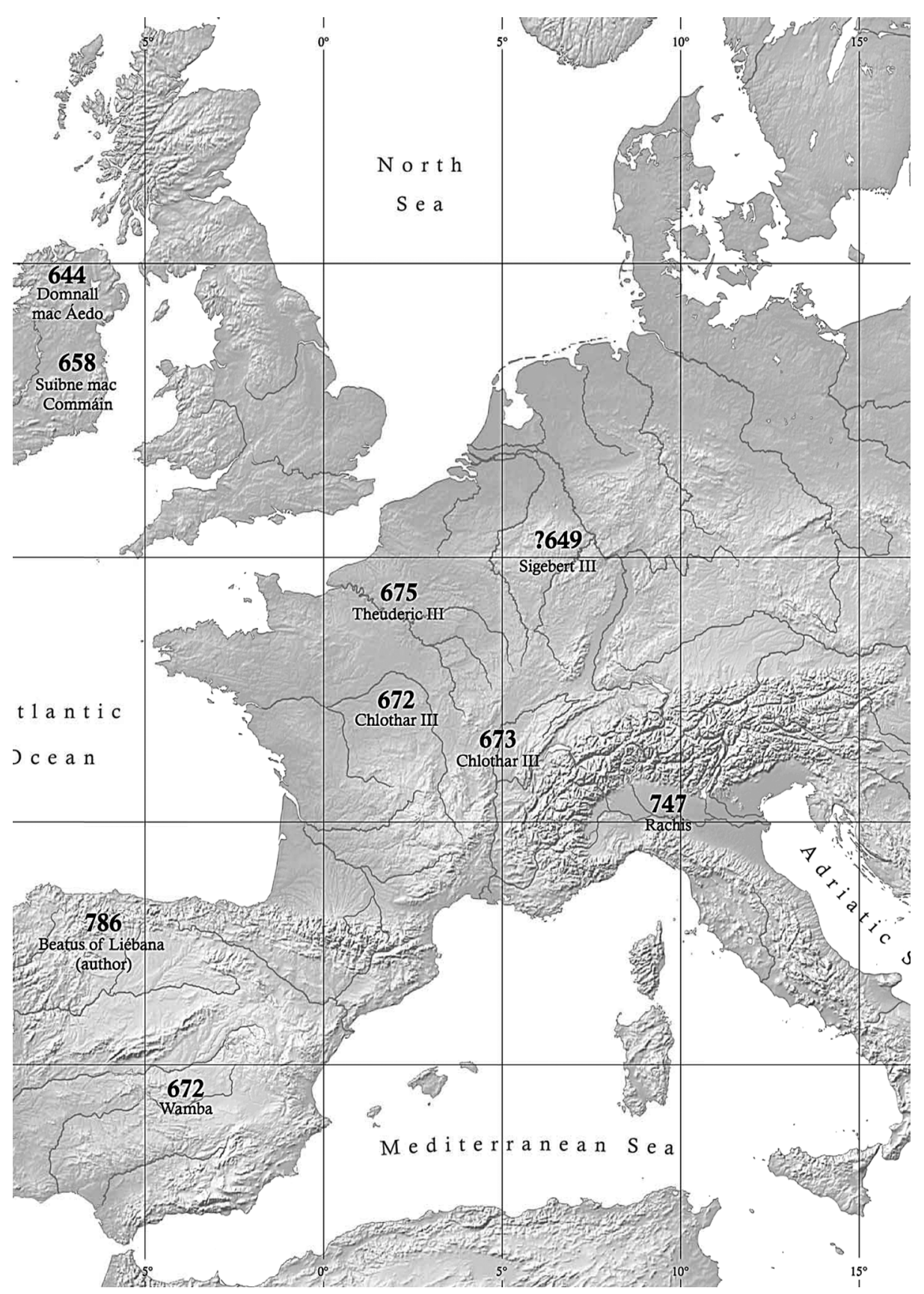

Fig. 1: Mapping of countdowns to the end of the sixth millenium in seventh- and eighth-century Europe (@ Mappa Mundi Carthography) 
However, whether these countdowns to the end of the world really do reflect widespread apocalyptic anxiety among the general populace remains to be analysed. Certainly, the concentration of countdowns in the first half of the A.D. 670s is very striking. The evidence comes from four different manuscript contexts (continuations of Isidore's chronicle; Frankish summae annorum; Victorian computus; and the non-Isidorean Iberian tradition) and from four different geographic regions (Neustria, Burgundy, Aquitaine, Iberia). The text of all four dating clauses is essential for the following analysis:

\section{2: León AC 8 (saec. XI), 25v:}

Ab incarnatione autem domini nostri Ihesu Christi usque ad presentem primum glorissimum [recte glorissimi] Wambanis principis annum, qui est era DCCX, sunt anni DCCLXII [recte DCLXXII $\left.{ }^{13}\right]$.

$A b$ exordio autem mundi usque ad presentem et primum Wambanis annum, qui est era DCCX, colligitur anni $\bar{V} D C C C L X X I I$. Et in era DCCCXXXVIII completi fuerint anni $\bar{V} I$.

From the incarnation of our lord Jesus Christ to the present, first year of the most glorious King Wamba, which is era 710 , there are 672 years.

From the beginning of the world to the present and first year of Wamba, which is era 710, 5872 year are collected. And in era 838, 6000 years will have been completed. ${ }^{14}$

672: Paris BnF Lat. 17544 (saec. XII), 114r:

Post hanc supputationem usque in annum praesentem, quo Chlotharius exercitum contra Wascones movit, id est quintodecimo regni ipsius, additi sunt anni LX a tempore item Chlotharii abavi ipsius, in quo anno apostolicus vir domnus Chado episcopus et Barcelaicus abbas basilicam sancti Sulpicii a fundamento edificare ceperunt circa illam priorem, ubi in corpore requiescit. Qui annus centesimus tercius decimus cum bissexto in ciclo Victorii repperitur et ab obitu sancti Sulpicii XXus VIus esse probatur. Sunt ab exordio mundi usque ad predictum tempus anni $\bar{V} D C C C L X X I I I$. De sexto vero miliario supersunt anni CXXVII.

Quia idem Victorius a duobus Geminis et tempore passionis Christi cum consulibus in suo ciclo usque ad Constantinum et Rufum illius anni consules intimavit annos CCCCXXX et sine consulibus CII. Et ab initio mundi usque ad predictum annum, quo Constantinus et Rufus consules erant, titulavit in suo prologo annos esse VDDCLVIII. Peractis illis centum et duobus sine consulibus, quos ipse futuros scripsit, et CXIII de recapitulatione cicli invenies summam annorum superius intimatam, id est $\bar{V} D C C C L X X I I I$.

13 The correction is confirmed by Florence BML Plut.20.54, 45v (http://mss.bmlonline.it/s.aspx? Id=AVsVHEIgkUprGCn5XSfO\&c=II.\%20Isidori\%20iunioris\%20Chronographia,\%20cum\%20prologo\#/oro/96).

14 León AC 8 is available online at http://bvpb.mcu.es/es/consulta/registro.cmd?id=449895. There is a beautiful facsimile edition of the codex in Liber Antiphonarium, curated by Cuesta. See also Warntjes, "The Final Countdown and the Reform of the Liturgical Calendar in the Early Middle Ages," 54-55. All translations, unless stated otherwise, are mine. 
According to this count, up to the present year, in which Chlothar led an army against the Basques, i.e. the 15th year of his reign, 60 years are added to the time of Chlothar, the greatgrandfather of this one, in which year the apostolic man, lord, and bishop Chado and the abbot Barcelaicus began to build from its foundation the church of the Holy Sulpicius around that earlier place, where he [Sulpicius] rested in the flesh. This year is found as the 113th with bissextus [= AP $645=$ A.D. 672] in the cycle of Victorius, and from the death of Sulpicius it is proven to be the 26th. There are 5873 years from the beginning of the world to the aforementioned time. Of the sixth millennium, however, 127 years remain.

This is because the same Victorius published in his cycle 430 years with consuls from the two Gemini and the time of the passion of Christ to the consuls Constantine and Rufus of his own year, and 102 years without consuls. In his prologue, he argued that from the beginning of the world to that year in which Constantine and Rufus were consuls, 5658 years had passed. After those 102 years without consuls, which he tabulated as future ones, had passed, and 113 of the return of the cycle, you will find the sum of years given above, i.e. $5873 .^{15}$

673: Milan BA H 150 inf. (saec. IX), 129v:

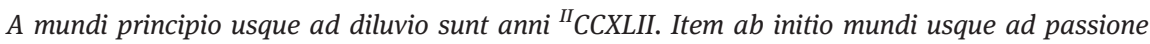
domini nostri Jesu Christi sunt anni $\bar{V} C C X X V I I I$. Similiter ab initio mundi usque eo tempore quando ciclo isto Victurius condedit sunt anni $\bar{V} D C X L V I I I$. In summa enim ab initio mundi usque in presente anno, id est sexto decimo anno regnante Chlotario filio Chlodoueo, sunt anni $\bar{V} D C C C L X X I I I I$. Restant de sexto miliario anni CXXVI.

From the beginning of the world to the Flood are 2242 years. Likewise, from the beginning of the world to the passion of our lord Jesus Christ are 5228 years. Likewise, from the beginning of the world to the time when Victorius invented that very cycle are 5648 years. In total, from the beginning of the world to the present year, i.e. the sixteenth year of the reign of Chlothar, son of Chlodovech, are 5874 years. 126 years remain of the sixth millennium. ${ }^{16}$

675: Oxford BL e Mus. 113 (saec. X/XI), 114v-115r:

A passione domini nostri Ihesu Christi usque ad transitum Childeberti regis, in quo anno cyclus Victurii rurso ex passione dominica circulum annorum ad inicium rediit, sunt anni DXXXII. In summa ab inicio mundi usque in praedicto anno sunt anni $\bar{V} D C C L X$. Ab eo anno usque primo anno regni Chlotharii filii Chlodouei sunt anni LXXXVIIII [recte LXXXXVIIII]. Ab inde usque transitum illius, quando Heldericus germanus suus tria hec regna Neustria, Austria, et Burgundia subiugauit, sunt anni quindecim et menses [erasure] V; Hildericus regnauit in Neustria annos II et menses VI. Cui germanus suus Teodericus successit in regno. Ab eo anno, quando passus est dominus nostri Ihesus Christus, usque primo anno Teoderici regis anni sunt DCLXVIII [recte DCXLVIII]. Fiunt insimul ab inicio mundi usque in predicto primo anni [recte anno] regni Teoderici incliti regis anni $\bar{V} D C C C L X X$ et VI. Et restat de sexto miliario anni CXXIIII. Explicit.

15 Additamenta ad chronica maiora, ed. Mommsen, 493, with correction by Krusch, "Die Zusätze zu den Chroniken Isidors," 365. Warntjes, "The Final Countdown and the Reform of the Liturgical Calendar in the Early Middle Ages," 56-57.

16 For this dating clause see especially Krusch, "Die Einführung des griechischen Paschalritus im Abendlande," 132; Warntjes, The Munich Computus, LXXIII-IV; Warntjes, "The Final Countdown and the Reform of the Liturgical Calendar in the Early Middle Ages," 59. 
From the Passion of our Lord Jesus Christ up to the death of King Childebert - in which year the cycle of Victorius returned from the Lord's Passion to the beginning of the cycle of years there are 532 years. In total, from the beginning of the world up to the aforementioned year, there are 5,760 years. From this year up to the first year of the reign of Chlothar, son of Clovis, there are 89 [recte 99] years. From then up to his death, when his brother Childeric subjugated these three kingdoms of Neustria, Austrasia, and Burgundy, there are 15 years and 5 months. Childeric reigned in Neustria for 2 years and 6 months. His brother Theuderic succeeded him in the kingdom. From this year, when our Lord Jesus Christ suffered, up to the first year of the reign of Theuderic, there are 668 [recte 648] years. These make altogether, from the beginning of the world up to the aforesaid first year of the reign of the renowned king Theuderic, 5876 years. And there remain 124 years of the sixth millennium. The end. ${ }^{17}$

The first year in this cluster of countdowns is A.D. 672. In order to understand what triggered such a widespread use of chronological millennialism at that particular moment, it is essential to analyse this crucial year in detail.

\section{The Year A.D. 672}

In the early Middle Ages, apocalyptic fear was usually generated by warfare, famine, pestilence, rare and disturbing astronomical phenomena (such as eclipses, comets, or solar activity), earthquakes, or extreme weather. In the period under discussion here, between c. A.D. 640 and 800, the Arab invasion of the Iberian Peninsula from A.D. 711 onwards was the most cataclysmic political change (though it only indirectly influenced Beatus of Liébana's commentary on the apocalypse, which contained the last countdown listed in Table 1 above). Likewise, the Viking incursions in Britain and Ireland starting in the A.D. 790s had a similar effect (and are more directly connected to the contemporary apocalyptic discourse).$^{18}$ Both events, however, took place too late to explain the cluster of chronological millennialism under discussion here.

Outside of the political sphere, the A.D. 660s saw the highest density of unsettling and catastrophic events in the seventh and eighth centuries, starting with the famous total solar eclipse of A.D.664, which was followed by plague and widespread famine. While the Annals of Ulster only transmit some cryptic entries, ${ }^{19}$ Bede provides a fuller narrative, specifying that the plague depopulated large areas

17 The passage is transcribed (and discussed) in Additamenta ad chronica maiora, ed. Mommsen, 491-492; Waitz, "Handschriften in englischen Bibliotheken," 383; Krusch, "Chronologie der merowingischen Könige," 477-481, and Krusch, "Die Einführung des griechischen Paschalritus im Abendlande,” 133. Cf. also Krusch, "Die Zusätze zu den Chroniken Isidors,” 365; Warntjes, "The Final Countdown and the Reform of the Liturgical Calendar in the Early Middle Ages," 56-57.

18 Palmer, The Apocalypse in the Early Middle Ages, 176-183.

19 Annals of Ulster s.a. 663 (= 664), ed. and trans. Mac Airt and Mac Niocaill, 134-135. 
of Anglo-Saxon England and Ireland..$^{20}$ The plague's devastating consequences and its prominent place in the collective memory of the Irish and Anglo-Saxons can also be seen in Adomnán's Life of Columba, written around A.D. 700. This saint's life is divided into three books, on prophecies, miracles, and angelic apparitions, respectively. The second book ends with Saint Columba's patronage and spiritual guidance protecting the regions of modern-day Scotland from the plague. ${ }^{21}$ It may well be that the apocalyptic countdowns of the A.D. 670s are a delayed reaction to the problems faced in the previous decade. However, the events just described took place in Britain and Ireland, whereas the countdowns of the A.D. 670s originated exclusively on the Continent. ${ }^{22}$

Three of the four countdowns under scrutiny here, dating to the years from A.D. 672 to 675, can be placed in Neustria, Burgundy, and north-eastern Aquitaine. Because of the explicit references to reigning Neustrian-Burgundian kings, James Palmer considered a political background the most likely scenario. ${ }^{23}$ The second and third countdown transcribed above refer to the 15th and 16th year of the Neustrian-Burgundian king Chlothar III, respectively. The fourth provides more detail, stating that Chlothar III died after ruling for 15 years and 5 months, and that his reign was followed by the tyranny in Neustria of Childeric II who reigned for 2 years and 5 months. This reign, in turn, came to an end with the accession of Theuderic to the Neustrian throne. This last countdown certainly smacks of political partisanship, but to connect all three countdowns to the power struggle between Childeric II, Bishop Leudegard of Autun, and the Neustrian mayor of the palace Ebroin seems

20 See especially Bede, Historia ecclesiastica, 3.27, ed. Plummer, Venerabilis Baedae Opera historica, 1, 191-194; trans. Colgrave and Mynors, Bede’s Ecclesiastical History, 311, 313, 315. For the apocalyptic context of this passage, see Foot, "Plenty, Portents and Plague," 27-29. For the plague in Britain and Ireland in the early Middle Ages (including good overviews of the sources), see Maddicott, "Plague in Seventh-Century England;" Dooley, "The Plague and its Consequences."

21 Adomnán, Vita Columbae, 2.46, ed. and trans. by Anderson and Anderson, Adomnán's Life of Columba, 178-181; cf. the new translation by Sharpe, Adomnán of Iona, 203-204, with commentary 348-349. Adomnán's references to the plague are discussed, though in a different context and with rather controversial results, by Woods, “Adomnán, Plague and the Easter Controversy."

22 For an overview of occurrences of the plague on the Continent in the second half of the seventh century, see Biraben and Le Goff, "La peste dans le haut moyen age," 1492-1497 (interestingly, the authors do not consider the epidemic described in Insular sources for the A.D. 660s to have been the plague; more generally, Britain and Ireland do not feature in their discussion). Obviously, the scarcity of sources available for this time and place may distort the picture; certainly, the Life of St Eligius of Noyon (ed. Levison, 669-742) seems to suggest that the plague of the A.D. 660s also hit at least the border region between Austrasia and Neustria: chapter 2.41 (724-725) relates a vision shortly after Eligius's death concerning Queen Balthild; Eligius had died in A.D. 660, Balthild in A. D. 680 (and, more generally, the Vita was composed by Bishop Audoin of Rouen, whose death is recorded for A.D. 686); chapter 2.43 (725-726) then narrates that "at the same time, a plague (morbus) devastated most violently many of the cities of Francia”, but a certain Ingomar in the city of Thérouanne was spared through his veneration for Eligius.

23 Palmer, “The Ordering of Time,” 617; Palmer, The Apocalypse in the Early Middle Ages, 86, 91. 
to telescope events anachronistically. Particularly the first of the three countdowns appears to have been written before the conflict broke out, which, however, turned into a large-scale political crisis only at Chlothar's death and Childeric II accession. ${ }^{24}$ Also, the last of these three countdowns, written at the end of the conflict, could have explicitly referred to it, but chose to remain silent. James Palmer's hypothesis that the Frankish political conflict triggered the production of apocalyptic countdowns also cannot account for the production of the one from Visigothic Spain, a kingdom unconnected to Neustrian politics at this time. More convincing would have been the observation that two of the four countdowns described above mark the first year of rule of the respective king (Wamba and Theuderic III) and therefore could have been composed to commemorate the respective change in rulership. However, for this purpose a simple summa annorum, counting the years to the accession of the new king, would have been enough, there was no need for adding a countdown to the end of the sixth millennium.

\section{The Victorian Computus}

Since there is no conclusive evidence that the "traditional" causes of widespread apocalyptic fear were at play in the A.D. 670s, the decade's cluster of dating clauses containing apocalyptic countdowns must have been triggered by something else. Since their authors belonged to the Christian intellectual elite, the trigger may have been a theological or intellectual problem, rather than a political event or a social, celestial, or natural phenomenon. This brings us back to the textual and manuscript context of the countdowns in question. The countdown of A.D. 673 in the Milan MS is embedded in the computistical writings of Victorius of Aquitaine, sandwiched between the latter's prologue and Easter table, here covering the years AP 1-120 and 144-154 (the latter wrongly labeled 121-131; this is equivalent to A.D. 560-679 and 703-713). The dating clauses written as a continuation of Isidore of A.D. 672 and the Summa annorum of A.D. 675, respectively, explicitly use Victorius's Easter table as one of their central dating components. Three of the four countdowns in question, therefore, present a direct link to Victorius's Easter table. The Aquitanian's paschal calculations may therefore provide the solution to the problem.

In the second century, followers of the still emerging Christian belief decided that their highest religious feast day, commemorating the crucifixion and resurrection of their saviour, was not to be celebrated on a fixed Julian calendar date.

24 For the background of this conflict, see especially Dupraz, Contribution à l'histoire du regnum Francorum, 354-369; Ewig, "Die fränkischen Teilreiche im 7. Jahrhundert," repr. in Ewig, Spätantikes und fränkisches Gallien, at 213-216; and also idem, Merowinger und das Frankenreich, 160-161; Geary, Before France and Germany, 189-190; Gerberding, Rise of the Carolingians, 69-71. For the difficulties in dating this conflict, see Dupraz, "Essai sur une chronologie nouvelle," 552-561. 
Rather, following the information provided in the Gospels, the first Sunday after the full moon occurring at the time of the Hebrew lunar month Nisan (the first month of spring) was proclaimed the correct date. The connection of Easter to the lunar phases (or the synodic lunar month, i.e. the period from one new or full moon to the next) proved fateful. The developing Eastern churches, with their intellectual centre in Alexandria, favoured a 19-year lunar cycle, while the emerging Western church with Rome at its core first experimented with an 8-year lunar cycle, before embracing, in the late third and early fourth centuries, an 84-year lunar cycle. This variation in practice led to ongoing disputes between Alexandria and Rome, which the pope found increasingly embarrassing. ${ }^{25}$ In A.D. 457, Pope Leo I commissioned Victorius, a renowned mathematician from Aquitaine, with the task of bringing the Western calculations in line with the East.

Creating an Easter table is not an easy undertaking, as the amount of numerical data to be processed is considerable. Certainly, it seems that for centuries after Victorius no further attempt was made at establishing a more accurate system: besides other considerations, it must have been deemed too complex a task. Following the Alexandrian example, Victorius opted for a 19-year lunar cycle, though the structure of his version differed from the Alexandrian one in a number of details. ${ }^{26}$ Since a 19year lunar cycle is not compatible with the 28-year weekday cycle (after all, Easter had to be celebrated on a Sunday), the result of Victorius's efforts was a (19x28=) 532-year Easter table. ${ }^{27}$

There were three reasons why some of these 532 years proved problematic for later users of Victorius's table.

25 For the late antique Easter controversy between Rome and Alexandria and the underlying Easter cycles, see especially Schwartz, "Christliche und jüdische Ostertafeln;" Schmid, Osterfestberechnung in der abendländischen Kirche, 1-60; Chaîne, Chronologie des temps chrétiens, 19-70; van de Vyver, "Évolution du comput alexandrine;" Declercq, Anno Domini, 49-82; Mosshammer, The Easter Computus and the Origins of the Christian Era, 109-316; Nothaft, Dating the Passion, 35-80. 26 The differences are most prominently discussed in Jones, "Victorian and Dionysiac Paschal Tables," repr. in idem, Bede, the Schools and the Computus.

27 Victorius's computistica consist of a full 532-year Easter table and a letter to archdeacon (later pope) Hilarus, which serves as a prologue to said table. His computistica are edited by Krusch, "Studien zur christlich-mittelalterlichen Chronologie," 4-57. For this Easter reckoning, see especially Ideler, Handbuch der mathematischen und technischen Chronologie, vol. 2, 275-285; Schwartz, "Christliche und jüdische Ostertafeln," 72-80; Bedae opera, ed. Jones, 61-68; Declercq, Anno Domini, 82-95; Declercq, "Dionysius Exiguus," 181-187; Mosshammer, The Easter Computus and the Origins of the Christian Era, 239-244; Holford-Strevens, "Paschal Lunar Calendars up to Bede," 192196. 


\subsection{Two Dates for Easter Sunday in certain Years}

Victorius was supposed to reconcile Roman with Alexandrian tradition. A first step was to abandon the Roman 84-year Easter table and to adopt a 19-year lunar cycle. But there were further differences between Eastern and Western practice. The most important one, from a theological perspective, was the differing lunar limits of Easter Sunday: Since Easter was agreed to fall on the first Sunday after the first full moon (luna 14) after the spring equinox, the lunar age on this day could vary by seven days. The Roman church set their lunar limits from luna 16 to 22 in accordance with the lunar age implied by St John's Gospel for the resurrection (luna 16). The Alexandrian church, on the other hand, allowed Easter to fall between luna 15 to 21 , commemorating the crucifixion according to the Synoptic Gospels (luna 15) ${ }^{28}$ and the limits for the Jewish feast of unleavened bread as outlined in Leviticus. ${ }^{29}$ Put in (over)simplified language, when Alexandria allowed Easter Sunday to fall on luna 15 (the day immediately following the first full moon after the vernal equinox), Rome would postpone by a week to luna 22. In the prologue to his Easter table, Victorius explained that he noted both Alexandrian luna 15 and Roman luna 22 in the relevant years in order to accommodate both traditions. ${ }^{30}$ However, he did not do this consistently for every year in which his system allowed Easter Sunday on luna 22; a comprehensive study of how exactly he set the double dates remains a major desideratum in modern scholarship. ${ }^{31}$ What was designed as an act of diplomacy earned Victorius the scorn of later commentators, who accused him of not providing clarity where clarity was needed. Victor of Capua, replying to the pope's question about the Easter date for A.D. 550, was furious that Victorius provided both a correct (though with the wrong lunar date) and a wrong date for this year. ${ }^{32}$ The Irish peregrinus in Francia, Columbanus, argued that Victorius "defined nothing where it was

28 For the difference between John and the Synoptic Gospels in dating Jesus's passion, see especially Nothaft, Dating the Passion, 23-24.

29 Leviticus 23:5-6.

30 Victorius of Aquitaine, Prologus, 11 (Krusch, "Studien zur christlich-mittelalterlichen Chronologie," 26): Illud praeterea insinuari non destiti propter diversiorum paschalium conditores, ubi in hoc eodem cyclo dies paschae gemina designatione positus invenitur, id est ubi luna XV. die dominica et post septem dies vicensima secunda conscribitur, non meo iudicio aliquid definitum, sed pro ecclesiarum pace apostolici pontificis electioni servatum, quatenus nec ego, quod ad meum pertinebat officium, praeterirem, et in eius constitueretur arbitrio, qui universali ecclesiae praesiderit, quaenam potissimum dies, in tali condicione sollemnitati praecipuae deputetur. Nam ceteris, quae e latere similiter adiecta sunt, non firmatur auctoritas, sed varia significatur opinio.

31 The starting point for this investigation must be Krusch, "Über eine Handschrift des Victurius," 274-275; Krusch, "Studien zur christlich-mittelalterlichen Chronologie," 12-15; Warntjes, The Munich Computus, LXXXIV-V n 228.

32 The passage in question is transmitted by Bede in De temporum ratione, 51, ed. Jones, Bedae opera, 272-273; trans. Wallis, Bede, 135). Bede provides another lengthy quote from Victor of Capua in his Epistola ad Wicthedum 8 (ed. Jones, Bedae opera, 322-323; trans. Wallis, Bede, 421-422). This latter and more fragments of Victor of Capua's De pascha are printed by Pitra, Spicilegium Soles- 
necessary" in his letter to the Gaulish clergy of A.D. $603 .^{33}$ The monk Leo, writing in Visigothic Spain in A.D. 627, complained along similar lines. ${ }^{34}$ Many Victorian Easter tables from the later seventh and eighth centuries, however, dropped the double dates, no doubt to give them more authority and to avoid confusion. ${ }^{35}$ But from the mid-fifth to the mid-seventh centuries, Victorian doubles dates were considered a problem of his Easter reckoning, rather than an elegant way of reconciling two divergent traditions. ${ }^{36}$

The other two reasons for problematic years in Victorius's table can best be explained on the basis of a chart created by Daniel Mc Carthy: ${ }^{37}$

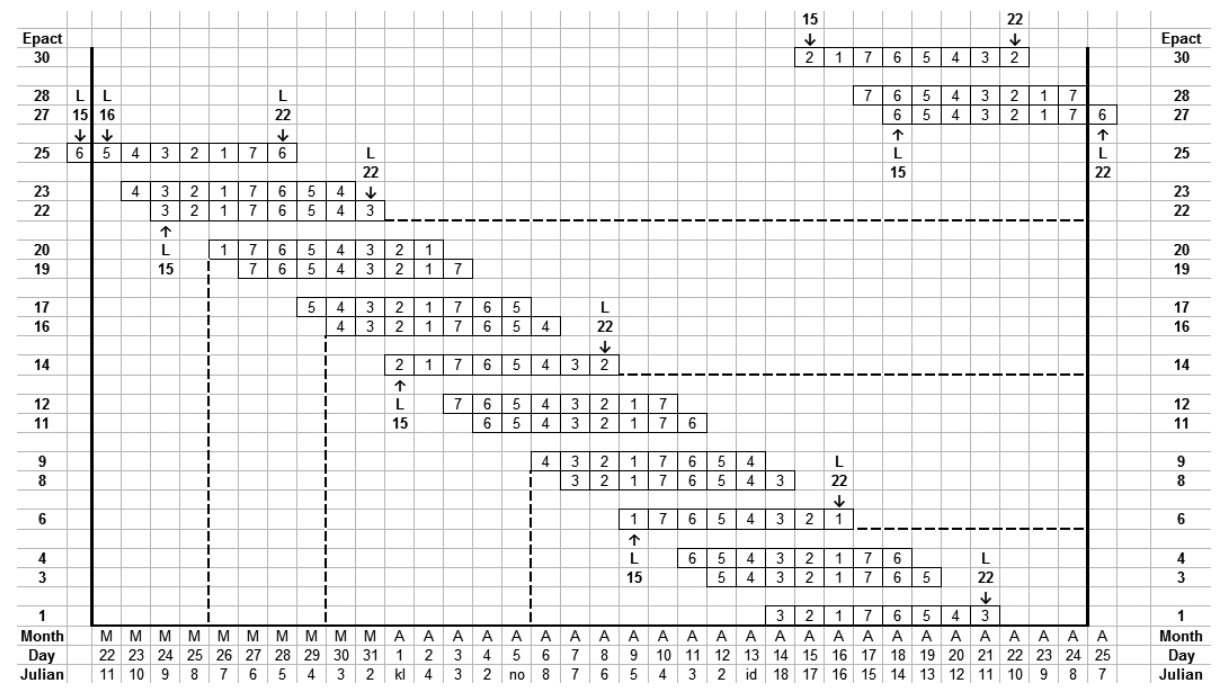

Fig. 2: The Julian calendar dates for Easter Sunday in Victorius's Easter reckoning, depending on the epact (lunar age) and weekday of 1 January.

mense, vol. 1, 296-301; Pitra worked from Paris BnF Lat. 12309, 87v-96r (information provided by Philipp Nothaft). The passage in question here is not among Pitra's fragments of Lat. 12309.

33 Columbanus, Epistolae, 2.7, ed. Walker, Opera, 18: iuxta Victorium nuper dubie scribentem et, ubi necesse erat, nihil definitem.

34 Leo monachus, Epistola ad Sesuldum, 2 (Krusch, "Studien zur christlich-mittelalterlichen Chronologie," 299): Sed illud me inter cetera movet, ubi ambigue duas opinions dies paschae uno eodemque anno prefixit. A new edition of this letter has just been published by Martín-Iglesias, "La Epistola de computo paschali".

35 For the manuscript transmission of Victorian Easter tables, see Warntjes, The Munich Computus, LXXXIV-LXXXV n 228. To these, add Paris BnF Lat. 10756 (saec. VIII), 67r, which transmits a Victorian Easter table for the years AP 161-165 = A.D. 720-724 (cf. Krusch, "Chronologisches aus Handschriften," 93-94); the manuscript was originally part of Bern BB 611, which contains the Victorian Dial. Burg. of A.D. 727 (cf. Hellmann, Tironische Noten in der Karolingerzeit am Beispiel eines PersiusKommentars aus der Schule von Tours, 225, 248).

36 See also Warntjes, "Victorius vs Dionysius," 86-87.

37 Slightly modified from Mc Carthy, "Paschal Cycle of St Patrick," 113. 
The Victorian Easter reckoning was based on a 19-year lunar cycle. This means that the lunar age of any given Julian calendar date will recur to the exact same value after exactly 19 years, but not before. In other words, if a certain Julian calendar date is fixed, say 1 January, it will have a different and characteristic lunar age for each of the 19 years. Therefore, each year of the 19-year lunar cycle can be defined by the characteristic lunar age of a fixed Julian calendar date. Victorius chose 1 January, and the lunar age on this date is called the epact. The epacts are listed in the vertical axis. The horizontal axis refers to the Julian calendar period that Victorius allowed for Easter Sunday, ranging from 22 March as the earliest possible date to 24 April as the latest. For any of the 19 years in Victorius's lunar cycle, Easter Sunday could fall on seven different consecutive dates, luna 16 to 22 (with Victorius also noting the alternative luna 15 if Easter fell on the latter date, as discussed above). Which of these was Easter Sunday in a given year depended on the weekday of 1 January; the weekdays are here numbered in early medieval fashion from 1 = Sunday to 7 = Saturday. For example, according to this chart, in a year with epact 3 and weekday 1 on 1 January, Easter Sunday fell on 16 April.

The problematic years occurred when the range of permissible lunar ages for Easter (luna 15 or 16, respectively, to luna 22) could not be accommodated within Victorius's Julian calendar limits for Easter Sunday of 22 March to 24 April, i.e. in years of epact 25 and 27 respectively:

\subsubsection{Epact 25}

In his prologue, Victorius explained that the Latini allowed the Easter new moon (luna 1) to fall as early as 5 March, ${ }^{38}$ which leads to Easter full moon (luna 14) on 18 March, and the earliest Easter Sunday (luna 16) on 20 March. This statement mislead Bede $^{39}$ and many modern commentators into thinking that Victorius was here explaining his own method. However, the word Latini here refers to the Roman method that Victorius was supposed to replace and to reconcile with Alexandria. Unlike the Alexandrians, who strictly observed Easter Sunday after the vernal equinox of 21 March, the Romans did not consider themselves bound by such a rule. For them, the key objective seems to have been that Easter was not to be celebrated on or later than 21 April, which marked the anniversary of the foundation of the city of Rome. Surely, the end of the Lenten fast and the commemoration of the passion of Christ could not coincide with the debauchery of pagan festivities. ${ }^{40}$ If 21 April was to be kept as an upper Julian calendar limit, Easter Sunday had to fall before

38 Victorius, Prologus, 4 (Krusch, "Studien zur christlich-mittelalterlichen Chronologie," 19).

39 Bede, De temporum ratione, 50-51 (ed. Jones, Bedae opera, 269-272; trans. Wallis, Bede, 131135).

40 This argumentation is evident through Prosper’s Chronica $\$ \$ 1351-1352$ (ed. and trans. into German by Becker and Kötter, Prosper Tiro, 124-125): CCCCXVII: Theodosio XVIII et Albino [AP 417= A.D. 
the vernal equinox of 21 March. Victorius had more flexibility. As will be outlined below, the brief he got from the papal curia allowed Easter Sunday as late as 24 April. This made it possible for Victorius to honour the vernal equinox of 21 March at least for Easter Sunday (as, e.g., Easter Sunday previously celebrated on 20 March luna 16 could now be postponed to 24 April luna 22). He still set the Easter full moon (luna 14) as early as 20 March (i.e., before the vernal equinox) every 19th year (in years with epact 25), which led to 22 March, luna 16 (i.e., after the vernal equinox) as the earliest possible date for Easter Sunday. For Victorius, it was important to observe the equinox-rule for Easter Sunday, not necessarily also for the Easter full moon. Therefore, Victorius's method allowed the equinox-rule to be strictly observed for Easter Sunday, which no previous Roman Easter reckoning had achieved to do. A potential problem for the date of Easter Sunday only arose in years in which 1 January not only fell on luna 25, but also on Friday (or Thursday in bissextile years). This led to Easter Sunday on 28 March, luna 22, or, alternatively (if double dates were applied), 21 March, luna 15 (i.e., on the equinox), which Alexandria considered unlawful. But none of the extant Victorian Easter tables records the "Greek" double date in such years (A.D. 471, 661, and 756), ${ }^{41}$ and it must be presumed that Victorius deliberately avoided them for these years in his original composition.

This still meant that every 19th year, the Easter full moon fell before the equinox. Victorius, from his Roman perspective, would not have seen any problem with this. Later commentators, like Bede, however, who were trained in the Alexandrian tradition, considered this "erroneous", "unjust", or "wicked". 42 Certainly by the seventh century, when the popularity of countdowns to the end of the sixth millennium grew, adherents of Victorius's calculations came increasingly under attack from the rising number of supporters of the Alexandrian (Dionysiac) reckoning. Every 19th year, the one with epact 25 in Victorius's Easter table, must have led to debates between the two opposing camps. ${ }^{43}$

\subsubsection{Epact 27}

Whereas the first aspect discussed here was simply a matter of preference, and the second one controversial only for those opposed to Victorius's system, the third

444]. hoc anno pascha domini VIII Kal. Mai. [= 23 April] celebratum est nec erratum, quia in die XI Kal. Mai. [= 21 April] dies passionis fuit. ob cuius reverentiam natalis urbis sine circensibus transiit. 41 Cf. Krusch, "Studien zur christlich-mittelalterlichen Chronologie," 32, 36, 46.

42 Bede uses the strongest language in De temporum ratione 51, which principally deals with Easter Sunday before the equinox, but chapter 50 leave no doubt that this applies equally to the Easter full moon before the equinox; cf. n. 39. Bede returns to the subject in De temporum ratione 61-62 (ed. Jones, Bedae opera, 281-284; trans. Wallis, Bede, 145-149). In chapter 61, he explicitly outlines the case of Easter Sunday falling after, the Easter full moon, however, before the equinox.

43 Cf. Warntjes, "Victorius vs Dionysius," 83-86. 
posed a real problem for followers of Victorius themselves. The brief given to Victorius by Pope Leo I must have explicitly forbidden for Easter Sunday to fall later than on 24 April. That date was already stretching the issue for the papal curia. In A.D. 444, Leo had agreed to 23 April for Easter Sunday as calculated by the Alexandrians, two days after the anniversary of the foundation of Rome. ${ }^{44}$ One of the arguments for accepting such a late date may have been that the commemoration of Christ's passion would fall on, but not after, 21 April. ${ }^{45}$ In A.D. 455, the situation was more delicate. According to the Alexandrian reckoning, Easter Sunday was supposed to fall on 24 April, and therefore Christ's passion would be commemorated on 22 April, the day after the anniversary of Rome's foundation. Maybe Rome here argued that at least the Easter full moon and the Last Supper fell on, and not after, 21 April, but there is no record of that. What is recorded is a series of letters exchanged between Leo and the Eastern Roman emperor as well as the patriarch of Alexandria, starting as early as A.D. 451, which illustrate the seriousness of the issue. ${ }^{46}$ In the end, Leo gave way and allowed Easter Sunday to be celebrated on 24 April in Rome. But when discussing the format of the new table to be designed by Victorius, Leo must have insisted that this was as far as the compromise in terms of Julian calendar dates for Easter Sunday would go: 25 April, the last possible date in the Alexandrian reckoning, was to be avoided. ${ }^{47}$

This put Victorius in a difficult position. His Easter table, with its 19-year lunar cycle starting with creation, the table proper with the year of Christ's passion and resurrection, was a very clever construction on various levels. Only in a year with epact 27 and Friday (or Thursday in bissextile years) on 1 January, which occurred

44 Cf. n. 40 above.

45 Paschasinus, Epistola ad Leonem, 2, ed. Krusch, "Studien zur christlich-mittelalterlichen Chronologie," 245-250 at 249: Nec nobis aut novum aut erratum videatur, cum dies passionis XI. die kalendarum maiarum occurrat, a qua, sicut Grecis videtur, pascha nomen accepit. Paschasinus does not mention the festivities in Rome in this context, but it shows an interesting parallel in argumentation with Prosper's passage cited n. 40 above, which does; Prosper is explicit that because of Christ's passion coinciding with the birthday of the city of Rome, no circus games took place.

46 The relevant letters are edited by Krusch, "Studien zur christlich-mittelalterlichen Chronologie," 251-265.

47 How problematic the acceptance by Leo of 24 April as Easter Sunday was perceived in Rome is evident through Prosper’s Chronica $\$ 1376$ (ed. and trans. Becker and Kötter, Prosper Tiro, 138-139): eodem anno pascha dominicum die VIII Kal. Mai. [= 24 April] celebratum est pertinaci intentione Alexandrini episcopi, cui omnes Orientales consentiendum putarunt, cum sanctus papa Leo XV Kal. Mai. [= 17 April] potius observandum protestaretur, in quo nec in ratione plenilunii nec in primi mensis limite fuisset erratum. extant eiusdem papae epistolae ad clementissimum principem Marcianum datae, quibus ratio veritatis sollicite evidenterque patefacta est et quibus ecclesia catholica instrui potest, quod haec persuasio studio unitatis et pacis tolerate sit potius quam probate, numquam deinceps imitanda, ut, quae exitialem attulit offensionem, omnem in perpetuum perdat auctoritatem. Prosper may have been an advisor to Leo in chronological questions relating to Easter; cf. James, "Leo the Great and Prosper of Aquitaine," 563-564. More generally on the relation between Prosper and Leo, see now Kötter, "Prosper von Aquitanien und Papst Leo der Große.” 
four times in 532 years, did the Aquitanian mathematician's method face insurmountable problems. In those instances, Easter Sunday should fall on 25 April with luna 22 according to Victorius's rules, but in violation of his Julian calendar limits for Easter Sunday of 22 March to 24 April; only the Alexandrian alternative, luna 15 on 18 April, appeared acceptable. Accordingly, Victorius failed to produce a lawful "Latin" date in years with those chronological characteristics.

How Victorius envisaged solving that problem is difficult to reconstruct. Interestingly, Victorius discussed only one year of his Easter table in detail, which is indeed one of epact 27, but with Saturday (rather than the problematic Friday) on 1 January. ${ }^{48}$ In such years, he argued, Easter Sunday could only be celebrated on 20 March according to the Latins, which had never been done, or on 24 April according to the Alexandrians, which had been observed a few times (no doubt referring to Leo's concession of A.D. 455). As this discussion constituted the final paragraph of his prologue, Victorius suggested that 24 April was the latest possible date for Easter Sunday in his Easter table. If this is what he intended to argue here, surely his solution for the problematic year of epact 27 and Friday (or Thursday in bissextile years) on 1 January was not to celebrate Easter Sunday on 25 April, luna 22. The only option was the "Alexandrian" luna 15, with no "Latin" alternative.

That this is what Victorius had in mind is confirmed by the oldest copy of the full Victorian 532-year Easter table, preserved in Gotha FB Membr. I 75, 77v-106r. For the first two occurrences of these problematic chronological combinations, the years AP 18 and 113, the Gotha table only provides one date for Easter Sunday, 18 April (luna 15). For the remaining two instances, AP 360 and 455, the Gotha table lists a second date, the erroneous 24 April (luna 22) ascribed to the Greeks. ${ }^{49}$ Obviously, 24 April was a Saturday rather than a Sunday in those years. Since this mistake appears twice in the Gotha table, and is confirmed for AP 455 (= A.D. 482) by the oldest (partial) Victorian table, known as the Paschale Campanum,,$^{50}$ there cannot be any doubt that Victorius himself listed these dates. Therefore, for years with epact 27 and Friday (or Thursday in bissextile years) on 1 January, Victorius even introduced falsified data in order to hide (or at least obscure) the fact that he was unable to produce an Easter Sunday in line with his own set of criteria.

Later commentators found cleverer solutions. Victorius (like Dionysius) did not provide details about the construction of his 19-year lunar cycle. In particularly, he never specified the exact place of the embolisms, the intercalated lunar months that

48 Victorius, Prologus, 12 (Krusch, "Studien zur christlich-mittelalterlichen Chronologie," 26): Cum vero contigerit, luna vicensima septima sabbato vel maxime die Kalendarum ianuarium provenire absque bissextum, noverit sanctitas tua, pascha nisi aut XIII. Kal. aprl. secundum Latinos, quod numquam caelebratum, etiamsi luna conveniat, penitus invenitur, aut VIII. Kal. mai. secundum Aegyptios, quod aliquotiens observatum est, reperiri non posse.

49 Gotha FB Membr. I 75, 78r, 83v (Krusch, "Studien zur christlich-mittelalterlichen Chronologie," 27, 32, 44, 49).

50 The Paschale Campanum (Vatican BAV Reg. lat. 2077, 96v-98r) is ed. Mommsen, 746. 
would bring the $354^{1 / 4}$-day lunar year in line with the $365^{1 / 4}$-day solar year. Seventh- and eighth-century computists, therefore, had some room for interpretation. As far as I am aware at present, only three tabular reconstructions of the details of Victorius's 19-year lunar cycle survive:

1. Bern BB 645, 55r-56v, probably composed around A.D. 696 in north-eastern France. ${ }^{51}$

2. Paris BnF Lat. 10756, 64v-66v; this originally formed part of Bern BB 611, which also contains a Victorian Computus of A.D. 727, possibly composed around Luxeuil. ${ }^{52}$

3. The final chapter of Quaest. Austr. of A.D. 764, uniquely transmitted in the famous codex Cologne DB 83-II of A.D. 805 (206v-213v). ${ }^{53}$

The Bern version differs markedly from its Paris and Cologne counterparts not least because it begins with the year of epact 1 on 1 January (coinciding with the first year to which Victorius's table could have been applied, A.D. 458), while the other two chose the year of epact 9 (the Victorian equivalent to the first year of the Dionysiac 19-year cycle) as their starting point. For the year in question (epact 27), however, all three texts follow the same doctrine (spelled out in most detail in Quaest. Austr.): Whereas Victorius's original Easter table suggested that the embolism of that year had to be intercalated before Easter Sunday, here the embolism is pushed to 3 May to 1 June. ${ }^{54}$ This leads to a lunar age for Easter Sunday incremented by one com-

51 For the Computus of A.D. 696 that contains the table in question see Krusch, "Studien zur christlich-mittelalterlichen Chronologie," 7-8; Cordoliani, "Les plus anciens manuscrits de comput ecclésiastique," 104-109, 111-112; Warntjes, "Köln als naturwissenschaftliches Zentrum in der Karolingerzeit," 58. For a discussion of the Victorian lunar cycle in question here, see HolfordStrevens, "Paschal Lunar Calendars up to Bede," 194-196.

52 The Victorian Computus of A.D. 727 was first edited by Krusch in "Studien zur christlich-mittelalterlichen Chronologie," 53-57; a new edition under the abbreviated title Dial. Burg. can be found in Borst, Schriften zur Komputistik im Frankenreich, 348-374. Cf. also Table 1 and n. 35 above.

53 Quaest. Austr. is edited by Borst, Schriften zur Komputistik im Frankenreich, 462-508, here 496508. For a discussion of the Victorian lunar cycle in question here, see Holford-Strevens, "Paschal Lunar Calendars up to Bede," 194-196.

54 The sequence of lunar ages on the calends (the first day) of each month in this year is: January 27, February 28, March 27, April 28 (29 in Bern is a scribal mistake), May 29, June 30, July 1, ... This means that the May lunation ends on 2 May with luna 30, followed by another full lunation of 30 days, the embolism, starting on 3 May and ending on 1 June, followed by the hollow June lunation of 29 days ending on 30 June. Quaest. Austr. 2.11 (year VIII; Borst, Schriften zur Komputistik im Frankenreich, 500-501) provides a slightly different explanation, but to the same effect: the hollow lunation (of 29 days) ending on 2 April is supposed to be considered the embolism and the 13th and last lunation of the lunar year; the following May lunation of 30 days is the first lunation of the following lunar year (and therewith the Easter lunation); this, however, is contrary to Latin customs, which insists on seven lunations of 30 days in embolismic years; therefore, the Egyptians turn this $13^{\text {th }}$ lunation into one of 30 days (this is Victorius' practice), which leads to epact 28 (rather than 29) on 1 May. The passage reads (with punctuation changed from Borst's edition): Kalendas Aprilis 
pared to Victorius's original table, and thus a lawful Easter Sunday of 18 April, luna 16 (rather than luna 15 as Victorius would have it) in the year in question. ${ }^{55}$

A year of epact 27 with the embolism before Easter Sunday

\begin{tabular}{|c|c|c|c|c|c|c|c|c|c|c|c|c|c|}
\hline & $\mathbf{J}$ & $\mathbf{F}$ & $\mathbf{M}$ & $\mathbf{A}$ & $\mathbf{M}$ & $\mathbf{J}$ & $\mathbf{J}$ & $\mathbf{A}$ & $\mathbf{S}$ & $\mathbf{O}$ & $\mathbf{N}$ & $\mathbf{D}$ & $\mathbf{J}$ \\
\hline $\mathbf{1}$ & 27 & 28 & 27 & 28 & 28 & 30 & 1 & 2 & 4 & 4 & 6 & 6 & 8 \\
\hline $\mathbf{2}$ & 28 & 29 & 28 & 29 & 29 & 1 & 2 & 3 & 5 & 5 & 7 & 7 & \\
\hline $\mathbf{3}$ & 29 & 1 & 29 & 30 & 1 & 2 & 3 & 4 & 6 & 6 & 8 & 8 & \\
\hline $\mathbf{4}$ & 30 & 2 & 30 & 1 & 2 & 3 & 4 & 5 & 7 & 7 & 9 & 9 & \\
\hline $\mathbf{5}$ & 1 & 3 & 1 & 2 & 3 & 4 & 5 & 6 & 8 & 8 & 10 & 10 & \\
\hline $\mathbf{6}$ & 2 & 4 & 2 & 3 & 4 & 5 & 6 & 7 & 9 & 9 & 11 & 11 & \\
\hline $\mathbf{7}$ & 3 & 5 & 3 & 4 & 5 & 6 & 7 & 8 & 10 & 10 & 12 & 12 & \\
\hline $\mathbf{8}$ & 4 & 6 & 4 & 5 & 6 & 7 & 8 & 9 & 11 & 11 & 13 & 13 & \\
\hline $\mathbf{9}$ & 5 & 7 & & 6 & 7 & 8 & 9 & 10 & 12 & 12 & 14 & 14 & \\
\hline $\mathbf{1 0}$ & 6 & 8 & & 7 & 8 & 9 & 10 & 11 & 13 & 13 & 15 & 15 & \\
\hline $\mathbf{1 1}$ & 7 & 9 & 7 & 8 & 9 & 10 & 11 & 12 & 14 & 14 & 16 & 16 & \\
\hline $\mathbf{1 2}$ & 8 & 10 & 8 & 9 & 10 & 11 & 12 & 13 & 15 & 15 & 17 & 17 & \\
\hline $\mathbf{1 3}$ & 9 & 11 & & 10 & 11 & 12 & 13 & 14 & 16 & 16 & 18 & 18 & \\
\hline $\mathbf{1 4}$ & 10 & 12 & 10 & 11 & 12 & 13 & 14 & 15 & 17 & 17 & 19 & 19 & \\
\hline $\mathbf{1 5}$ & 11 & 13 & 11 & 12 & 13 & 14 & 15 & 16 & 18 & 18 & 20 & 20 & \\
\hline $\mathbf{1 6}$ & 12 & 14 & 12 & 13 & 14 & 15 & 16 & 17 & 19 & 19 & 21 & 21 & \\
\hline $\mathbf{1 7}$ & 13 & 15 & 13 & 14 & 15 & 16 & 17 & 18 & 20 & 20 & 22 & 22 & \\
\hline $\mathbf{1 8}$ & 14 & 16 & 14 & 15 & 16 & 17 & 18 & 19 & 21 & 21 & 23 & 23 & \\
\hline $\mathbf{1 9}$ & 15 & 17 & 15 & 16 & 17 & 18 & 19 & 20 & 22 & 22 & 24 & 24 & \\
\hline $\mathbf{2 0}$ & 16 & 18 & 16 & 17 & 18 & 19 & 20 & 21 & 23 & 23 & 25 & 25 & \\
\hline $\mathbf{2 1}$ & 17 & 19 & 17 & 18 & 19 & 20 & 21 & 22 & 24 & 24 & 26 & 26 & \\
\hline $\mathbf{2 2}$ & 18 & 20 & 18 & 19 & 20 & 21 & 22 & 23 & 25 & 25 & 27 & 27 & \\
\hline $\mathbf{2 3}$ & 19 & 21 & 19 & 20 & 21 & 22 & 23 & 24 & 26 & 26 & 28 & 28 & \\
\hline $\mathbf{2 4}$ & 20 & 22 & 20 & 21 & 22 & 23 & 24 & 25 & 27 & 27 & 29 & 29 & \\
\hline $\mathbf{2 5}$ & 21 & 23 & 21 & 22 & 23 & 24 & 25 & 26 & 28 & 28 & 30 & 1 & \\
\hline $\mathbf{2 6}$ & 22 & 24 & 22 & 23 & 24 & 25 & 26 & 27 & 29 & 29 & 1 & 2 & \\
\hline $\mathbf{2 7}$ & 23 & 25 & 23 & 24 & 25 & 26 & 27 & 28 & 30 & 1 & 2 & 3 & \\
\hline $\mathbf{2 8}$ & 24 & 26 & 24 & 25 & 26 & 27 & 28 & 29 & 1 & 2 & 3 & 4 & \\
\hline $\mathbf{2 9}$ & 25 & & 25 & 26 & 27 & 28 & 29 & 1 & 2 & 3 & 4 & 5 & \\
\hline $\mathbf{3 0}$ & 26 & & 26 & 27 & 28 & 29 & 30 & 2 & 3 & 4 & 5 & 6 & \\
\hline $\mathbf{3 1}$ & 27 & & 27 & & 29 & & 1 & 3 & & 5 & & 7 & \\
\hline
\end{tabular}

A year of epact 27 with the embolism on 3 May to 1 June

\begin{tabular}{|c|c|c|c|c|c|c|c|c|c|c|c|c|c|}
\hline & $\mathbf{J}$ & $\mathbf{F}$ & $\mathbf{M}$ & $\mathbf{A}$ & $\mathbf{M}$ & $\mathbf{J}$ & $\mathbf{J}$ & $\mathbf{A}$ & $\mathbf{S}$ & $\mathbf{O}$ & $\mathbf{N}$ & $\mathbf{D}$ & $\mathbf{J}$ \\
\hline $\mathbf{1}$ & 27 & 28 & 27 & 28 & 29 & 30 & 1 & 2 & 4 & 4 & 6 & 6 & 8 \\
\hline $\mathbf{2}$ & 28 & 29 & 28 & 29 & 30 & 1 & 2 & 3 & 5 & 5 & 7 & 7 & \\
\hline $\mathbf{3}$ & 29 & 1 & 29 & 1 & & 2 & 3 & 4 & 6 & 6 & 8 & 8 & \\
\hline $\mathbf{4}$ & 30 & 2 & 30 & 2 & 2 & 3 & 4 & 5 & 7 & 7 & 9 & 9 & \\
\hline $\mathbf{5}$ & 1 & 3 & 1 & 3 & 3 & 4 & 5 & 6 & 8 & 8 & 10 & 10 & \\
\hline $\mathbf{6}$ & 2 & 4 & 2 & 4 & & 5 & 6 & 7 & 9 & 9 & 11 & 11 & \\
\hline $\mathbf{7}$ & 3 & 5 & 3 & 5 & & 6 & 7 & 8 & 10 & 10 & 12 & 12 & \\
\hline $\mathbf{8}$ & 4 & 6 & 4 & 6 & & 7 & 8 & 9 & 11 & 11 & 13 & 13 & \\
\hline $\mathbf{9}$ & 5 & 7 & 5 & 7 & & 8 & 9 & 10 & 12 & 12 & 14 & 14 & \\
\hline $\mathbf{1 0}$ & 6 & 8 & 6 & 8 & 8 & 9 & 10 & 11 & 13 & 13 & 15 & 15 & \\
\hline $\mathbf{1 1}$ & 7 & 9 & 7 & 9 & 9 & 10 & 11 & 12 & 14 & 14 & 16 & 16 & \\
\hline $\mathbf{1 2}$ & 8 & 10 & 8 & 10 & 10 & 11 & 12 & 13 & 15 & 15 & 17 & 17 & \\
\hline $\mathbf{1 3}$ & 9 & 11 & 9 & 11 & 11 & 12 & 13 & 14 & 16 & 16 & 18 & 18 & \\
\hline $\mathbf{1 4}$ & 10 & 12 & 10 & 12 & 12 & 13 & 14 & 15 & 17 & 17 & 19 & 19 & \\
\hline $\mathbf{1 5}$ & 11 & 13 & 11 & 13 & 13 & 14 & 15 & 16 & 18 & 18 & 20 & 20 & \\
\hline $\mathbf{1 6}$ & 12 & 14 & 12 & 14 & 14 & 15 & 16 & 17 & 19 & 19 & 21 & 21 & \\
\hline $\mathbf{1 7}$ & 13 & 15 & 13 & 15 & 15 & 16 & 17 & 18 & 20 & 20 & 22 & 22 & \\
\hline $\mathbf{1 8}$ & 14 & 16 & 14 & 16 & 16 & 17 & 18 & 19 & 21 & 21 & 23 & 23 & \\
\hline $\mathbf{1 9}$ & 15 & 17 & 15 & 17 & 17 & 18 & 19 & 20 & 22 & 22 & 24 & 24 & \\
\hline $\mathbf{2 0}$ & 16 & 18 & 16 & 18 & 18 & 19 & 20 & 21 & 23 & 23 & 25 & 25 & \\
\hline $\mathbf{2 1}$ & 17 & 19 & 17 & 19 & 19 & 20 & 21 & 22 & 24 & 24 & 26 & 26 & \\
\hline $\mathbf{2 2}$ & 18 & 20 & 18 & 20 & 20 & 21 & 22 & 23 & 25 & 25 & 27 & 27 & \\
\hline $\mathbf{2 3}$ & 19 & 21 & 19 & 21 & 21 & 22 & 23 & 24 & 26 & 26 & 28 & 28 & \\
\hline $\mathbf{2 4}$ & 20 & 22 & 20 & 22 & 22 & 23 & 24 & 25 & 27 & 27 & 29 & 29 & \\
\hline $\mathbf{2 5}$ & 21 & 23 & 21 & 23 & 23 & 24 & 25 & 26 & 28 & 28 & 30 & 1 & \\
\hline $\mathbf{2 6}$ & 22 & 24 & 22 & 24 & 24 & 25 & 26 & 27 & 29 & 29 & 1 & 2 & \\
\hline $\mathbf{2 7}$ & 23 & 25 & 23 & 25 & 25 & 26 & 27 & 28 & 30 & 1 & 2 & 3 & \\
\hline $\mathbf{2 8}$ & 24 & 26 & 24 & 26 & 26 & 27 & 28 & 29 & 1 & 2 & 3 & 4 & \\
\hline $\mathbf{2 9}$ & 25 & & 25 & 27 & 27 & 28 & 29 & 1 & 2 & 3 & 4 & 5 & \\
\hline $\mathbf{3 0}$ & 26 & & 26 & 28 & 28 & 29 & 30 & 2 & 3 & 4 & 5 & 6 & \\
\hline $\mathbf{3 1}$ & 27 & & 27 & & 29 & & 1 & 3 & & 5 & & 7 & \\
\hline
\end{tabular}

Fig. 3: Two possible constructions of a year of the Victorian 19-year lunar cycle with epact 27 on 1 January. The lunar age of every day for each month from January to December are listed in succsessive columns, with abbreviations for the respective month in bold in the first line and the dates of month in bold in the first column. The embolism is highlighted in red, and the lunar age on the critical date, 18 April, in yellow.

This alteration of Victorius's original calculation did not simply remain theoretical; two seventh- and eighth-century Victorian Easter tables confirm that it was also applied in practice. The first of these, covering the years AP 141-212 [=A.D. 700-771], is transmitted in Paris BnF Lat. 4860 (Reichenau, saec. IX ${ }^{\mathrm{ex}}$ ), 147v-148r and Vatican BAV Reg. lat. 586 (Lake Constance region, saec. IX ${ }^{\text {inf }}$ ), 9r-10v. Years of epact 27 oc-

luna vicesima octava. IIII. Nonas Aprilis luna vicesima nona deficit. III. Nonas Aprilis prima luna, quae luna Maii est et luna primi mensis. De hac luna Hieronimus ait: Interdum incipit in Aprili. Contra consuetudinem embolismorum luna Aprilis, quae vicesima nona esse <dicitur $>$, hac vice tertia decima esse deputatur luna. Ut hoc embolesmo iuxta Latinos septem lunae tricesimae inveniantur, ideo Aegyptii hanc lunam tricesimam esse putant. Epactae Aegyptiorum viginti octo. Kalendas Maii luna vicesima nona.

55 See Holford-Strevens, "Paschal Lunar Calendars up to Bede," 194 n. 57. 
cur four times in this table. In the first instance, AP 151, the lunar age of Easter Sunday is in line with the canonical Victorian Easter table; in the remaining three cases (AP 170, 189, 208), however, the lunar age of Easter Sunday is systematically incremented by one compared to Victorius's original construction, no doubt because of the later placement of the embolism discussed above. More important for the present study is the second table, preserved in Milan BA H 150 inf. (Bobbio, saec. $\mathrm{IX}^{1 / 3}$ ), 130r-132r, covering the years AP 1-120 and 144-154 (wrongly labeled 121131). Years of epact 27 occur seven times in this table (AP 18, 37, 56, 75, 94, 113, 151). In four of these instances (AP 18, 37, 56, 113), the lunar age of Easter Sunday is incremented by one compared to the canonical Victorian Easter table. Crucially, two of those four increments coincide with the only two years in the range of this table that contain the problematic combination of epact 27 and Friday (or Thursday in bissextile years) on 1 January. Therefore, this table consistently and systematically solves Victorius's problem by providing an acceptable lunar age for Easter Sunday in years AP 18 and 113, 18 April, that is, luna 16 (rather than Victorius's luna 15).

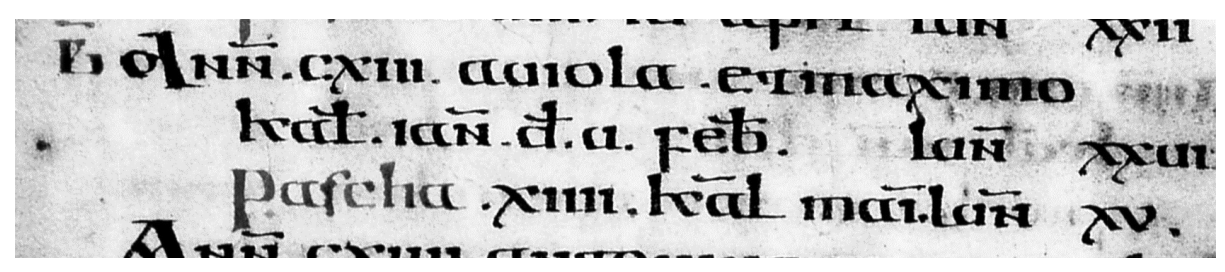

Fig. 4: AP 113 in Gotha FB Membr. I 75, 84r

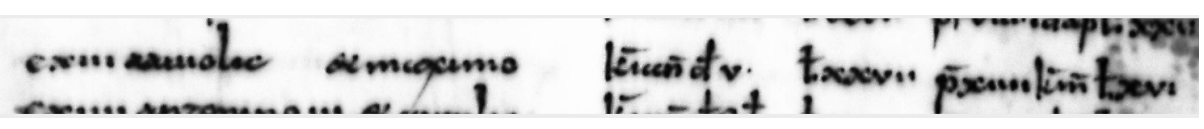

Fig. 5: AP 113 in Milan BA H inf. 150, 132r

Interestingly, in the Milan codex the Victorian Easter table immediately follows the countdown of A.D. 673, and one wonders whether the alteration of the Victorian Easter table is connected to this countdown and its annus praesens.

\section{Gregory of Tours and the Easter of A.D. 577}

Clearly, this technical trick of shifting the embolism to after Easter in years of epact 27 was only introduced at some point in the second half of the seventh century (and may, in fact, have been a regional solution, restricted to northern Burgundy and Austrasia). Before then, a year with epact 27 and Friday (or Thursday in bissextile 
years) on 1 January created considerable controversy among the intellectual elite that promoted the Victorian method of reckoning.

Our best witness in this respect is Gregory of Tours. In his Ten Books of Histories, he includes two passages designed to illustrate the invocation of portents of the apocalypse that will follow if Easter is not celebrated on the right day. The most indicative statement comes towards the end of Gregory's text, and it is worth quoting in full:

Dubietas pascae fuit ob hoc, quod in cyclum Victuri luna XV. pascham scripsit fieri. Sed ne christiani ut Iudei sub hac luna haec solemnia celebrarent, addidit: Latini autem luna XXII. Ob hoc multi in Galiis XV. luna celebraverunt, nos autem XXII. Inquesivimus tamen studiosae, sed fontes Hispaniae, quae divinitus implentur, in nostrum pascha repleti sunt. Terrae motus factus est magnus XVIII. Kalendas mensis V., die IIII., prima mane, cum lux redire cepisset. Sol eclypsin pertulit mense VIII. mediante, et ita lumen eius minuit, ut vix, quantum quintae lunae cornua retinent, ad luscendum haberet. Pluviae validate, tonitrua in autumno gravia, aquae autem nimium invaluerunt. Vivariensim Avennicamque urbem graviter lues inguinaria devastavit.

\begin{abstract}
A dispute arose about the date of Easter, because Victorius, in his cycle, had written that Easter should be celebrated on the fifteenth day after the full moon. To prevent Christians holding the feast on the same day after the full moon as the Jews, Victorius added: 'The Church of Rome celebrates on the twenty-second day.' As a result many people in Gaul held Easter on the fifteenth day, but I myself kept the feast on the twenty-second day. I made careful inquiries and discovered that the Spanish Springs, which flow by divine agency, began to run on the day which I had chosen for Easter. There was a great earthquake very early in the morning on Wednesday, 14 June, just as the day began to dawn. There was an eclipse of the sun in the middle of October. The sun's rays were so diminished that it gave no more light than the horned moon when five days old. It rained in torrents, there were violent thunder-storms in Autumn and the river-waters rose very high. There was a serious outbreak of bubonic plague in the towns of Viviers and Avignon. ${ }^{56}$
\end{abstract}

The year in question is A.D. 590, and the problem the one outlined under 1 above: Victorius provided two dates for Easter Sunday in this year, 26 March (luna 15) and 2 April (luna 22). The first one was supposed to reflect Alexandrian customs, the second one Victorius attributed to the Latini ${ }^{57}$ Victorius thought the decision was the pope's to make. Gregory clearly did not have the same regard for Roman authority. A metropolitan bishop in Gaul held as much (if not more) power than the bishop of Rome, and there was no question of outside interference in spiritual matters; decisions were taken locally not centrally. ${ }^{58}$ Whether the choice made was right or wrong was not determined by inquiry in Rome, but by consultation of the holy wells

56 Gregory of Tours, Decem libri historiarum, 10.23, ed. Krusch, 514-515; trans. Thorpe, Gregory of Tours: Histories, 581-582.

57 Krusch, "Studien zur christlich-mittelalterlichen Chronologie," 28.

58 Prinz, "Die bischöfliche Stadtherrschaft im Frankenreich vom 5. bis zum 7. Jahrhundert," and Prinz, "Der fränkische Episkopat zwischen Merowinger- und Karolingerzeit," 110-133; Scheibelreiter, Bischof in merowingischer Zeit; Heinzelmann, Bischofsherrschaft in Gallien. 
in Spain, which obviously could only sanction or condemn the action retrospectively. ${ }^{59}$ More importantly, Gregory's narrative draws a direct connection between celebrating Easter on the wrong date and portents of the apocalypse: earthquakes, a solar eclipse, thunderstorms and torrential rain, plague. One wonders whether Gregory's contemporaries would have seen the fact that (according to the bishop's narrative) the plague raged most vehemently in Viviers and Avignon as direct punishment for not celebrating Easter on the correct date. Certainly, only two chapters later Gregory extends the list of divine punishment from plague to famine in other parts of Gaul, citing Matthew 24:7-8/Mark 13:22 on the signs of the End Times:

At in Galliis Masiliensim provintiam morbus saepe nominatus invasit. Andecavos, Namneticos atque Cenomaticos valida famis oppressit. Initia sunt enim haec dolorum iuxta illud quod Dominus ait in euangelio: Erunt pestilentiae et fames et terrae motus per loca; et exurgent pseudochristi et pseudoprophetae et dabunt signa et prodigia in caelo, ita ut electos in errore mittant, sicut praesenti gestum est tempore.

In Gaul the Bubonic plague which I have so often had occasion to mention attacked Marseilles. A terrible famine afflicted Angers, Nantes and Le Mans. These are the beginning of sorrows, as our Lord said in the Gospel: 'And there shall be famines, and pestilences, and earthquakes, in diverse places. For false Christs and false prophets shall rise, and shall shew signs and wonders in the sky, to seduce, if it were possible, even the elect.' That is exactly what happened at this time. ${ }^{60}$

The message was clear: celebrating Easter on the wrong date could lead to apocalyptic consequences.

But what, then, if the authoritative Easter table did not produce lawful Easter dates in certain years? Interestingly, Gregory's second passage on the Easter problem deals exactly with the case discussed under 3 above: a year of epact 27 and Friday on 1 January in the Victorian Easter table. He says that in this year, A.D. 577, some churches in Gaul, following the Spanish example, kept Easter Sunday on 21 March, while Tours and other cities preferred 18 April. ${ }^{61}$ The information provided by Gregory is rather sparse, and for very good reasons: 18 April, his Easter Sunday, fell on luna 15, a practice he was to condemn later in his work, in the passage cited above. Celebrating Easter Sunday on 21 March is an interesting alternative within

59 Krusch, "Studien zur christlich-mittelalterlichen Chronologie," 11 put it thus: "Bei den Doppeldaten des Victorius traten die Zweifelsfälle ziemlich häufig ein, und man forschte dann, an welchem Datum sich die Taufquellen in Spanien gefüllt hatten. War dies an dem gewählten Datum der Fall, so hatte man die Genugtuung, daß man richtig gefeiert hatte, im anderen Falle umgekehrt den Schmerz."

60 Gregory of Tours, Decem libri historiarum, 10.25, ed. Krusch, 517; trans. Thorpe, Gregory of Tours: Histories, 584.

61 Gregory of Tours, Historia Francorum, 5.17, ed. Krusch, 215: Eo anno dubietas paschae fuit. In Galliis vero nos cum multis civitatibus quarto decimo Kalendas Maias sanctum paschae celebravimus. Alii vero cum Spanis duodecimo Kalendas Aprilis solemnitatem hanc tenuerunt; tamen, ut ferunt, fontes illi, qui in Spaniis nutu Dei conplentur, in nostrum paschae repleti sunt. 
the Victorian system (not considered by its Aquitanian author), as its lunar age, luna 17 , is uncontroversial; ${ }^{62}$ but it meant commemorating the resurrection on rather than after the equinox, which was considered problematic in itself (see 2 above). Certainly, 25 April with luna 22 was not considered a possible date for Easter Sunday by followers of Victorius in Gaul or Spain, if Gregory can be trusted here. Gregory had an interest in not providing further information, and his own unease with the choice of Easter dates available to him that year is obvious in the remainder of this chapter: yes, the Spanish holy wells confirmed his date (18 April), but on the same day there was also an earthquake-like incident at the village of Chinon, while mass was held in honour of Christ's resurrection, followed by an outbreak of the plague. Gregory pointed out the problem, but had no solution.

\section{Conclusion}

The evidence provided by Gregory of Tours illustrates how conflicting or uncanonical data for the commemoration of the most important feast of Christianity caused distress among the Christian intellectual elite in Western Europe towards the end of the sixth century. The problems were caused by the construction of the Victorian Easter table, and followers of this system connected conflicting dates for Easter Sunday or unlawful data with portents of the end of the world. After the fateful year A.D. 577, the next year for which the Victorian table would provide no clear-cut lawful date was A.D. 672. We have no account similar to that provided by Gregory on the reactions to this intellectual dilemma, principally because the A.D. 670s are one of the least documented decades in Merovingian history. Certainly, the Christian elites had to act. One option was to tamper slightly with Victorius's Easter table by postponing the embolism and thereby creating an uncontroversial Easter date of 18 April, luna $16 .{ }^{63}$ This was done in Gaul, probably after substantial intellectual debate around the year A.D. 672 as witnessed by three of the four countdowns transcribed above. The other option was to replace the Victorian reckoning with its rival, the Alexandrian system in the guise of Dionysius's Easter table. The fourth countdown reflects this change, the one from Iberia with the reference to the Visigothic king Wamba. The few sentences provided, with its application of the incarnation era, could hardly have been more visionary, certainly from our retrospective viewpoint. Wamba, whose accession is commemorated here, was the first Christian king

62 Krusch, "Die Einführung des griechischen Paschalritus im Abendlande," 127-128, with his characteristic sharpness, rightly identified the celebration of Easter Sunday on 21 March as an alternative within the Victorian system (which he believed Victorius had envisaged himself). Englisch, "Ostern zwischen Arianismus und Katholizismus," 80-86, on the other hand, wants this to reflect some regional Visigothic custom, of which there is no conclusive evidence.

63 See Figures 3-5. 
for whom the anointment ritual was recorded, ${ }^{64}$ which was to define the Middle Ages from Pippin the Younger's anointment by Pope Stephen in A.D. 754 onwards and in some regions, like England (whose royal ruler is still anointed by the archbishop of Canterbury), persists to the present day. This passage contains one of the earliest uses of the incarnation era, which remains the standard in the 21st century. At the same time, the late date for Easter Sunday on 25 April (exclusive to the Alexandrian/Dionysiac system) celebrated by the Visigoths in this year was still viewed with considerable suspicion by the Iberian intellectual elites, a reminder of the Roman past of Iberia. ${ }^{65}$

Certainly, the four countdowns dating between A.D. 672 and A.D. 675 discussed in this article make it very clear that our knowledge of the connections drawn between present time and potential portents of the apocalypse in the early medieval Latin West exclusively stems from the writings of a Christian elite. This elite held the religious, moral, and intellectual monopoly, often coupled with considerable political power. Its members tried to play the apocalypse to their advantage (claiming moral superiority over their secular or ecclesiastical rivals, as in Gildas' case), which provides us with a sense of the internal and external threats this elite faced. Sometimes, however, as in the case of the countdowns to the end of the sixth millennium discussed here, apocalyptic allusions were simply the result of a theological and/or technical problem important to Christian intellectual circles alone, without any bearing on our understanding of the politics of the day, or even of the sentiments of a wider public. The thought-world of that elite was not that of the lay nobles, nor of the commoners. Their reflections were more often triggered by intellectual questions, problems, and challenges than by real-life experiences. The apocalyptic over- or undertones we find in early medieval Latin accounts are no exception to that rule.

\footnotetext{
64 Julian of Toledo, Historia Wambae regis 4, ed. Levison, 220. See Rovira, "La iglesia visigoda y los problemas de la sucesión al trono en el siglo VII," repr. in Rovira, Estudios visigoticos III, 54-56; Aguilera, Pensamiento político visigodo, 285-292; Claude, Adel, Kirche und Königtum, 154-161; Collins, "Julian of Toledo and the Royal Succession in Late Seventh-Century Spain;" Teillet, Des goths à la nation gothique, 585-624; de Jong, "Julian of Toledo," 378-382.

65 This is best illustrated by the Visigothic codex Paris BnF Lat. 609 (saec. IX), 76r, which contains a dating clause of A.D. 672 discussing the unusually late date for Easter Sunday in the Dionysiac reckoning for this year: Nostrum uero sanctum pascha per dies XXXV, qui faciunt septimanas $V, a b X I$ Kalendas Apriles usque in VIII Kalendas Maias, excepto uno, quod fuit sub era ab incarnatione Domini DCLXXII: XIIII Kalendas Maias die dominico Hebreorum pascha, et nostra VII Kalendas Maias luna XXIa, sicut et in preteritis iam fuit.
} 


\section{Bibliography}

\section{Abbreviations}

CCSL

Corpus Christianorum Series Latina. Turnhout: Brepols, 1953-.

MGH

MGH Auct. Ant. Monumenta Germaniae Historica. 1819-.

MGH SS rer. Merov. Scriptores rerum Merovingicarum

SC

Sources Chrétiennes. Paris: Édition du Cerf, 1941-.

\section{Primary Sources}

Additamenta ad chronica maiora. Edited by Theodor Mommsen, 491-494. MGH Auct. Ant. 11/2, Chronica minora, saec. IV-VII. Berlin: Weidmann, 1894.

Adomnán of Iona. Life of Columba. Edited and translated by Alan Orr and Marjorie Ogilvie Anderson. 2nd ed. Oxford: Clarendon Press, 1991; and also: Life of Columba. Translated by Richard Sharpe. London: Penguin Books, 1995.

The Annals of Ulster (to A.D. 1131). Edited and translated by Seán Mac Airt and Gearóid Mac Niocaill. Dublin: Dublin Institute for Advanced Studies, 1983.

Liber Antiphonarium de toto anni circulo a festivitate Sancti Aciscli usque ad finem, curated by Ismael Fernández de la Cuesta. Madrid: Ministerio de Cultura y Cabildo de la Santa Iglesia Catedral de León, 2011.

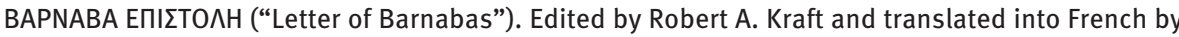
Pierre Prigent. Vol. 172, SC. Paris: Éditions du Cerf, 1971.

Bede. De temporum ratione. Edited by Charles W. Jones. Bedae opera de temporibus. Cambridge, MA: Mediaeval Academy of America, 1943. English translation: Bede. The Reckoning of Time. Translated by Faith Wallis. Liverpool: Liverpool University Press, 1999.

Bede. Historia ecclesiastica gentis Aglorum. Edited by Charles Plummer. 2 vols. Oxford: Oxford University Press, 1896. English translation: Bede. Ecclesiastical History.

Bede. Ecclesiastical History of the English People. Edited and translated by Bertram Colgrave and Roger A.B. Mynors. Oxford: Clarendon Press, 1969.

Columbanus. Epistolae. Edited and translated by G. S. M. Walker. Sancti Columbani Opera. Dublin: Dublin Institute for Advanced Studies, 1957, repr. 1997.

Vita Eligii episcopi Noviomagensis. Edited by Wilhelm Levison, MGH SS rer. Merov. 4, 669-742. Hannover, Leipzig: Hahn, 1912.

Gildas. De excidio et conquestu Britanniae. Edited by Theodor Mommsen, MGH Auct. Ant. 13, Chronica minora. 1-85. Berlin: Weidmann, 1898. English translation: Gildas. The Ruin of Britain and other Works. Edited and translated by Michael Winterbottom. London: Phillimore, 1978.

Gregory of Tours. Decem libri historiarum. Edited by Bruno Krusch, MGH SS rer. Merov. 1,1, 1-537. Hannover: Hahn, 1951. English translation: Gregory of Tours. The History of the Franks. Translated by Lewis Thorpe. London: Penguin Books, 1974.

Leo monachus. Epistola. Edited and translated into Spanish by José Carlos Martín-Iglesias. "La Epistola de computo paschali (CPL 2300) del monje León: nueva edición y estudio de una obra probablemente hispano-visigoda." Rivista di Cultura Classica e Medioevale 61 (2019), 205239. 
Julian of Toledo. Historia Wambae regis. Edited by Wilhelm Levison. CCSL 115. Turnout: Brepols, 1976.

The Munich Computus: Text and Translation: Irish Computistics between Isidore of Seville and the Venerable Bede and its Reception in Carolingian Times. Edited and translated by Immo Warntjes. Vol. 59, Sudhoffs Archiv: Beihefte. Stuttgart: Steiner Verlag, 2010.

Paschale Campanum (Vatican BAV Reg. lat. 2077, 96v-98r). Edited by Theodor Mommsen, MGH Auct. ant. 9, 744-750. Berlin: Weidmann, 1892.

Prosper Tiro. Chronik: laterculus regum Vadalorum et Alanorum. Edited and translated into German by Maria Becker and Jan-Markus Kötter. Paderborn: Schöningh, 2016.

Spicilegium Solesmense complectens Sanctorum Patrum scriptorumque ecclesiasticorum anecdota hactenus opera. Vol. 1. Edited by Jean-Baptiste Pitra. Paris: Firmin Didot, 1852.

Victorius of Aquitaine. Computistica. Edited by Krusch, "Studien zur christlich-mittelalterlichen Chronologie," 4-52.

\section{Secondary Literature}

Aguilera, Barbero Abilio de. "El pensamiento político visigodo y las primeras unciones regias en la Europa medieval.” Hispania: Revista española de historia 30 (1970): 245-326.

Biraben, Jean-Noël, and Jacques Le Goff. "La peste dans le haut moyen age." Annales: histoire, sciences sociales 24, no. 6 (1969): 1484-1510.

Borst, Arno, Schriften zur Komputistik im Frankenreich von 721 bis 818. 3 vols. Monumenta Germaniae Historica, Schriften zur Geistesgeschichte. Hannover: Hahn, 2006.

Burgess, Richard W., and Witold Witakowski, Studies in Eusebian and Post-Eusebian Chronography. Stuttgart: Steiner, 1999.

Chaîne, Marius. La chronologie des temps chrétiens de l'Égypte et de l'Éthiope. Paris: Geuthner, 1925.

Claude, Dietrich. Adel, Kirche und Königtum im Westgotenreich. Sigmaringen: Thorbecke, 1971.

Collins, Roger. "Julian of Toledo and the Royal Succession in Late Seventh-Century Spain." In Early Medieval Kingship, edited by Peter H. Sawyer and Ian Wood, 30-49. Leeds: University of Leeds, 1977, repr. 1979.

Collins, Roger. The Arab Conquest of Spain 710-797. Oxford: Blackwell, 1989.

Cordoliani, Alfred. "Les plus anciens manuscrits de comput ecclésiastique de la bibliothèque de Berne.” Zeitschrift für Schweizerische Kirchengeschichte 51 (1957): 101-112.

Cuppo, Luciana. "Felix of Squillace and the Dionysiac Computus I: Bobbio and Northern Italy (MS Ambrosiana $\mathrm{H} 150$ inf.)." In The Easter Controversy of Late Antiquity and the Early Middle Ages: its Manuscripts, Texts, and Tables: Proceedings of the 2nd International Conference on the Science of Computus, Galway, 18-20 July 2008, edited by Immo Warntjes and Dáibhí Ó Cróinín, 110-136. Turnhout: Brepols, 2011.

Declercq, Georges. Anno Domini: The Origins of the Christian Era. Turnhout: Brepols, 2000.

Declercq, Georges. "Dionysius Exiguus and the Introduction of the Christian Era." Sacris Erudiri 41 (2002): 165-246.

Dooley, Ann. "The Plague and its Consequences in Ireland." In Plague and the End of Antiquity: The Pandemic of 541-750, edited by Lester K. Little, 215-228. Cambridge: Cambridge University Press, 2007.

Dupraz, Louis. Contribution à l'histoire du regnum Francorum pendant troisième quart du VII siècle (656-680). Fribourg: St. Paul, 1948. 
Dupraz, Louis. "Essai sur une chronologie nouvelle des regnes de Clotaire III (657-673) et de Childéric II (662-675)." Schweizerische Zeitschrift für Geschichte = Revue suisse d'histoire = Rivista storica svizzera 2 (1952): 525-568.

Englisch, Brigitte. "Ostern zwischen Arianismus und Katholizismus: Zur Komputistik in den Reichen der Westgoten im 6. und 7. Jh." In The Easter Controversy of Late Antiquity and the Early Middle Ages: Its Manuscripts, Texts, and Tables: Proceedings of the $2^{\text {nd }}$ International Conference on the Science of Computus, Galway, 18-20 July 2008, edited by Immo Warntjes and Dáibhí Ó Cróinín, 76-109. Turnhout: Brepols, 2011.

Ewig, Eugen. "Die fränkischen Teilreiche im 7. Jahrhundert (613-714)." Trierer Zeitschrift 22 (1953): 85-144, repr. in Eugen Ewig, Spätantikes und fränkisches Gallien: gesammelte Schriften (1952-1973). 3 vols., vol. 1, edited by Hartmut Atsma et al., 172-230. Zürich: Artemis, 19762009.

Ewig, Eugen. Die Merowinger und das Frankenreich. 3rd ed. Stuttgart, Berlin, Köln: W. Kohlhammer, 1997.

Foot, Sarah. "Plenty, Portents and Plague: Ecclesiastical Readings of the Natural World in Early Medieval Europe." In God's Bounty? The Churches and the Natural World, edited by Peter Clarke and Tony Claydon, 15-41. Woodbridge: Ashgate, 2010.

Fried, Johannes. "Endzeiterwartung um die Jahrtausendwende." Deutsches Archiv für Erforschung des Mittelalters 45 (1989): 381-473.

Fried, Johannes. Aufstieg aus dem Untergang: Apokalyptisches Denken und die Entstehung der modernen Naturwissenschaften. Munich: C. H. Beck, 2001.

Geary, Patrick. Before France and Germany: The Creation and Transformation of the Merovingian World. Oxford: Oxford University Press, 1988.

Gerberding, Richard A. The Rise of the Carolingians and the Liber Historiae Francorum. Oxford: Clarendon Press, 1987.

Haeusler, Martin. Das Ende der Geschichte in der mittelalterlichen Weltchronistik. Köln: Böhlau, 1980.

Heinzelmann, Martin. Bischofsherrschaft in Gallien: Zur Kontinuität römischer Führungsschichten vom 4. bis zum 7. Jahrhundert. Zürich: Thorbecke, 1976.

Hellmann, Martin. Tironische Noten in der Karolingerzeit am Beispiel eines Persius-Kommentars aus der Schule von Tours. Hannover: Hahn, 2000.

Higham, Nick J. The English Conquest: Gildas and Britain in the Fifth Century. Manchester, New York: Manchester University Press, 1994.

Holford-Strevens, Leofranc. "Paschal Lunar Calendars up to Bede.” Peritia 20 (2008): 165-208.

Ideler, Ludwig. Handbuch der mathematischen und technischen Chronologie. 2 vols. Berlin: August Rücker, 1825-1826.

James, Norman W. "Leo the Great and Prosper of Aquitaine: A Fifth Century Pope and his Advisor." Journal of Theological Studies n.s. 44 (1993): 554-584.

Jones, Charles W. "The Victorian and Dionysiac Paschal Tables in the West." Speculum 9 (1934): 408-420, repr. in Charles W. Jones, Bede, the Schools and the Computus, edited by Wesley M. Stevens, 408-421. Aldershot: Variorum, 1994.

Jong, Mayke de. "Adding Insult to Injury: Julian of Toledo and his Historia Wambae." In The Visigoths from the Migration Period to the Seventh Century. An Ethnographic Perspective, edited by Peter J. Heather, 373-402. Woodbridge: Boydell, 1999.

Kötter, Jan-Markus. "Prosper von Aquitanien und Papst Leo der Große. Der Primat des Papstes im Spiegel einer zeitgenössischen Chronik." Römische Quartalsschrift für christliche Altertumskunde und Kirchengeschichte 111 (2016): 252-271.

Krusch, Bruno. "Die Chronicae des sogenannten Fredegar." Neues Archiv der Gesellschaft für ältere deutsche Geschichtskunde 7 (1882): 247-351, 421-516. 
Krusch, Bruno. “Zur Chronologie der merowingischen Könige.” Forschungen zur deutschen Geschichte 22 (1882): 449-490.

Krusch, Bruno. “Die Einführung des griechischen Paschalritus im Abendlande.” Neues Archiv der Gesellschaft für ältere deutsche Geschichtskunde 9 (1884): 99-169.

Krusch, Bruno. “Über eine Handschrift des Victurius.” Neues Archiv der Gesellschaft für ältere deutsche Geschichtskunde 9 (1884): 269-281.

Krusch, Bruno. “Chronologisches aus Handschriften.” Neues Archiv der Gesellschaft für ältere deutsche Geschichtskunde 10 (1885): 81-94.

Krusch, Bruno. “Die Zusätze zu den Chroniken Isidors.” Mitteilungen des Instituts für Österreichische Geschichtsforschung 18 (1897): 362-365.

Krusch, Bruno. "Studien zur christlich-mittelalterlichen Chronologie: die Entstehung unserer heutigen Zeitrechnung." Abhandlungen der Preußischen Akademie der Wissenschaften Jahrgang 1937, phil.-hist. Klasse 8 (1938).

Landes, Richard. "Lest the Millenium Be Fulfilled: Apocalyptic Expectations and the Pattern of Western Chronography 100-800 CE." In The Use and Abuse of Eschatology in the Middle Ages, edited by Werner Verbeke, Daniel Verhelst and Andries Welkenhuysen, 137-211. Leuven: Leuven University Press, 1988.

Landes, Richard. "The Fear of an Apocalyptic Year 1000: Augustinian Historiography, Medieval and Modern.” Speculum 75 (2000): 97-145.

Landes, Richard, Andrew Gow, and David C. van Meter eds. The Apocalyptic Year 1000: Religious Expectation and Social Change, 950-1050. Oxford: Oxford University Press, 2003.

Maddicott, John. "Plague in Seventh-Century England." In Plague and the End of Antiquity: the Pandemic of 541-750, edited by Lester K. Little, 171-214. Cambridge: Cambridge University Press, 2007.

Matter, Ann E. "The Apocalypse in Early Medieval Exegesis." In The Apocalypse in the Middle Ages, edited by Richard K. Emmerson and Bernard McGinn, 38-50. Ithaca, New York: Cornell University Press, 1992.

Matter, Ann E. "Exegesis of the Apocalypse in the Early Middle Ages." In The Year 1000: Religious and Social Response to the Turning of the First Millennium, edited by Michael Frassetto, 2940. New York: Palgrave Macmillan, 2002.

Mc Carthy, Daniel. "The Paschal Cycle of St Patrick." In Late Antique Calendrical Thought and its Reception in the Early Middle Ages, edited by Immo Warntjes and Dáibhí Ó Cróinín, 94-137. Turnhout: Brepols, 2017.

McKee, Ian. “Gildas: Lessons from History.” Cambrian Medieval Celtic Studies 51 (2006): 1-36.

Mosshammer, Alden A. The Chronicle of Eusebius and the Greek Chronographic Tradition. Lewisburg, PA: Bucknell University Press, 1979.

Mosshammer, Alden A. The Easter Computus and the Origins of the Christian Era. Oxford: Oxford University Press, 2008.

Nothaft, C. Philipp E. Dating the Passion: The Life of Jesus and the Emergence of Scientific Chronology (200-1600). Leiden: Brill, 2012.

Nothaft, C. Philipp E. “An Eleventh-Century Chronologer at Work: Marianus Scottus and the Quest for the Missing Twenty-two Years.” Speculum 88 (2013): 457-482.

Ó Cróinín, Dáibhí. “The Irish Provenance of Bede’s Computus.” Peritia 2 (1983): 229-247, repr. in Early Irish History and Chronology, edited by Dáibhí Ó Cróinín, 173-190. Dublin: Four Courts, 2003.

O'Sullivan, Thomas D. The De Excidio of Gildas: Its Authenticity and Date. Leiden: Brill, 1978.

Palmer, James T. “The Ordering of Time.” In Abendländische Apokalyptik: Kompendium zur Genealogie der Endzeit, edited by Veronika Wieser, Christian Zolles, Catherine Feik, Martin Zolles, and 
Leopold Schlöndorff, 605-618. Vol. 1, Cultural History of Apocalyptic Thought. Berlin: De Gruyter, 2013.

Palmer, James T. The Apocalypse in the Early Middle Ages. Cambridge: Cambridge University Press, 2014.

Poole, Kevin. "The Western Apocalypse Commentary Tradition of the Early Middle Ages." In A Companion to the Premodern Apocalypse, edited by Michael A. Ryan, 103-143. Vol. 64, Brill's Companions to the Christian Tradition. Leiden: Brill, 2016.

Prinz, Friedrich. "Die bischöfliche Stadtherrschaft im Frankenreich vom 5. bis zum 7. Jahrhundert." Historische Zeitschrift 217 (1973): 1-35.

Prinz, Friedrich. "Der fränkische Episkopat zwischen Merowinger- und Karolingerzeit." In Nascita dell'Europa ed Europa Carolingia: un'equazione da verificare, Spoleto: Fondazione Centro italiano di studi sull'alto medioevo, 1981, 101-130.

Rovira, José Orlandis. "La iglesia visigoda y los problemas de la sucesión al trono en el siglo VII." In Settimane di Studio del Centro italiano di studi sull'alto medioevo VII: Le chiese nei regni dell'Europa Occidentale e i loro rapporti con Roma fino all'800, Spoleto: Fondazione Centro italiano di studi sull'alto medioevo, 1960, 333-351, repr. In Estudios visigoticos III: El poder real y la sucesión al trono e la monarquia visigoda, Roma-Madrid: Consejo superior de investigaciones Cientificas Delegacion de Roma, 1962, 43-56.

Rühl, Franz. Chronologie des Mittelalters und der Neuzeit. Berlin: Reuther \& Reichert, 1897.

Scheibelreiter, Georg. Der Bischof in merowingischer Zeit. Wien: Böhlau, 1983.

Schipper, William. "Bede's Commentary on the Apocalypse and the Carolingians." In Das spätkarolingische Fragment eines illustrierten Apokalypse-Kommentars in der Mainzer Stadtbibliothek: Bilanz einer interdisziplinären Annäherung, edited by Annelen Ottermann, 148-171. Mainz: Landeshauptstadt Mainz, 2014.

Schmid, Joseph. Die Osterfestberechnung in der abendländischen Kirche. Freiburg: Herder, 1907.

Schustereder, Stefan J. Strategies of Identity Construction: The Writings of Gildas, Aneirin and Bede. Göttingen: V\&R Unipress, 2015.

Schwartz, Eduard. "Christliche und jüdische Ostertafeln.” Vol. 8, no. 6, Abhandlungen der königlichen Gesellschaft der Wissenschaften zu Göttingen, philologisch-historische Klasse. Berlin: Weidmann, 1905.

Teillet, Suzanne. Des goths à la nation gothique: les origines de l'idée de nation en Occident du $V^{e}$ au VII ${ }^{e}$ siècle. Paris: Les Belles Lettres, 1984.

Verbist, Peter. Duelling with the Past: Medieval Authors and the Problem of the Christian Era (c.990-1135). Turnhout: Brepols, 2010.

Vyver, André van de. "L'évolution du comput alexandrine et romain du III au Ve siècle." Revue d'histoire ecclésiastique 52 (1957): 5-25.

Waitz, Georg. "Handschriften in englischen Bibliotheken”, Neues Archiv der Gesellschaft für ältere deutsche Geschichtskunde 4 (1879): 323-393.

Warntjes, Immo. The Munich Computus: Text and Translation: Irish Computistics Between Isidore of Seville and the Venerable Bede and its Reception in Carolingian Times. Edited and translated by Immo Warntjes. Vol. 59, Sudhoffs Archiv: Beihefte. Stuttgart: Steiner Verlag, 2010.

Warntjes, Immo. "Köln als naturwissenschaftliches Zentrum in der Karolingerzeit: Die frühmittelalterliche Kölner Schule und der Beginn der fränkischen Komputistik." In Mittelalterliche Handschriften der Kölner Dombibliothek: Viertes Symposion der Diözesan- und Dombibliothek Köln zu den Dom-Manuskripten, edited by Heinz Finger and Harald Horst, 41-96. Vol. 28, Libelli Rhenani. Köln: Diözesanbibliothek Köln, 2012.

Warntjes, Immo. "Victorius vs Dionysius: The Irish Easter Controversy of AD 689." In Early Medieval Ireland and Europe: Chronology, Contacts, Scholarship; Festschrift for Dáibhí Ó Cróinín, edited 
by Pádraic Moran and Immo Warntjes, 33-98. Vol. 14, Studia traditionis theologiae. Turnhout: Brepols, 2015.

Warntjes, Immo. "The Final Countdown and the Reform of the Liturgical Calendar in the Early Middle Ages." In Apocalypse and Reform, edited by Matthew Gabriel and James T. Palmer, 51-75. New York: Routledge, 2018.

Woods, David. “Adomnán, Plague and the Easter Controversy.” Anglo-Saxon England 40 (2011): 1-13. 